\title{
Enhancing Transdisciplinary Learning through Community- Based Design Projects: Results from a Mixed Methods Study
}

\author{
Dr. Lindsey Payne \\ Assistant Professor, Ecological \& Environmental Engineering Program \\ Purdue University \\ paynel@purdue.edu \\ Dr. Brent Jesiek \\ Associate Professor, School of Engineering Education \\ Purdue University \\ bjesiek@purdue.edu
}

\begin{abstract}
To address complex sustainability challenges, solutions are needed that integrate the biophysical and sociocultural dimensions of sustainability. Engineers designing these solutions must be technically adept problem solvers, as well as effective at integrating the non-technical dimensions of sustainability into their design solutions. This paper reports on educational interventions in both a university engineering course and engineering servicelearning skill sessions. Using a mixed methods assessment approach to investigate the interventions, data were collected using a variety of instruments and analyzed using thematic analysis and appropriate statistical tests. Our findings include an increase in students' awareness and understanding of non-technical dimensions in design, and suggest that a transdisciplinary knowledge production model may enhance students' abilities to integrate non-technical dimensions, as well as engage with stakeholders, in community-based design projects. This study advances understanding of appropriate learning environments, teaching methods, and assessment tools for developing engineering competencies in sustainability problem solving.
\end{abstract}

Index Terms - Transdisciplinary, design, sustainability

\section{INTRODUCTION}

The world is faced with highly complex sustainability challenges. With increased recognition of the coupling of human and natural systems, emergent issues from these interconnections are putting additional stress on the planet and threatening sustainability. These socio-environmental issues transcend boundaries - spatial, temporal, sector, and disciplinary - and affect a variety of interest groups, thereby engaging diverse values, interests, and priorities. ${ }^{12}$ Solutions are needed to integrate the biophysical and sociocultural dimensions of sustainability. ${ }^{3} 45$ Engineers designing these solutions must be technically adept problem solvers and also effective at integrating the non-technical dimensions of sustainability into their design solutions.

Addressing today's sustainability challenges thus requires transdisciplinary collaboration across disciplinary boundaries, as well as among experts in industry, economics, politics, planning, and beyond. In these collaborative spaces, researchers have also suggested a specific set of needed competencies: systems-thinking competence, anticipatory competence, normative competence, strategic competence, and interpersonal competence. ${ }^{6}$ These competencies go beyond the 
International Journal for Service Learning in Engineering, Humanitarian Engineering and Social Entrepreneurship

Vol. 13, No. 1, pp. 1-52, Spring 2018

ISSN 1555-9033

traditional skill set of technically competent engineers. Future practicing engineers must also be able to understand the broader impact of sustainable design solutions, and be able to engage and collaborate across boundaries. ${ }^{789} 101112$

In recent years, scholars have recommended educational experiences for engineering students that aim to improve their understanding of the relationships between the environmental, social, political, and economic spheres of sustainability and how they affect design solutions. ${ }^{13} 1415$ ABET $^{16}$ similarly states that engineering graduates should possess a broader set of professional skills including the understanding of the impact of engineering solutions in a global, economic, environmental and societal context (ABET outcome 3h) and awareness of sustainability as a salient consideration when designing a system, component, or process (ABET outcome 3c). Environmental and professional organizations and accrediting agencies have also called for education in the area of sustainability to develop students' awareness and competencies toward creating a more sustainable future. ${ }^{17} 18$

This manuscript reports on an educational intervention in transdisciplinary learning and advances understanding of appropriate learning environments, teaching methods, and assessment tools for developing engineering competencies in sustainability problem solving. The paper begins with a literature review of such competencies, as well as a discussion of transdisciplinary knowledge production models and appropriate learning environments. Our findings are then presented along with implications for future work. Lessons learned and materials developed through this research are especially applicable to those in higher education, and specifically individuals teaching engineering students engaged in community-based design projects.

\section{LITERATURE REVIEW}

Developing competencies in sustainability problem solving represents a significant challenge to higher education. Engineering education has traditionally focused on technical problem solving, often without considering the associated social, political, and economic dimensions. ${ }^{19} 20$ Engineering students have historically been taught to draw boundaries that lead to right or wrong answers. $^{21} 22$ This contrasts to ways of knowing in the humanities and social sciences, which often thrive upon contributions to a broader conversation rather than claiming absolute truths. ${ }^{23}$ Still others have argued that being able to integrate and synthesize knowledge is a key competency for engineers. ${ }^{24}{ }^{25}$ More traditional engineering approaches, which tend to exclude non-technical dimensions in the problem solving and the design process, can distort problem definition and lead to inappropriate solutions for target uses and partner communities. ${ }^{26}$

To complement traditional engineering approaches, contemporary reforms to engineering education have integrated more design content into curricula and shifted to more open-ended and indeterminate problem solving. ${ }^{27}$ With a few notable exceptions, however, these reforms have not sufficiently addressed the non-technical dimensions of collaborative problem solving, ${ }^{29}$ and relatively little has changed in the kinds of engineering curricula that dominate the academic landscape. ${ }^{30}$ While while most current engineering programs intersperse humanities and social sciences coursework throughout the degree program in an attempt to address ABET outcome $3 \mathrm{~h}$ and broader university-wide general education requirements, this curricular model only tends to reinforce the dichotomy between engineering's technical core and its non-technical periphery. ${ }^{31}$ Ultimately, wider and deeper reforms are needed in engineering education, including revision of 
International Journal for Service Learning in Engineering, Humanitarian Engineering and Social Entrepreneurship

Vol. 13, No. 1, pp. 1-52, Spring 2018

ISSN 1555-9033

courses and curricula to include the non-technical dimensions of design and prepare engineering graduates for the sustainability challenges of the $21^{\text {st }}$ century. ${ }^{32} 3334$

\section{Transdisciplinary Models for Increasing Engineering Competencies}

In order to address complex sustainability problems, effective project design strategies for engineers will require a significant shift from traditional business-as-usual approaches in knowledge creation toward more socially engaged, context-sensitive, and transdisciplinary approaches. Transdisciplinary approaches to knowledge production can better account for the complexity of natural and human-made environments. ${ }^{35} 36373839{ }^{40}$ Such approaches go beyond traditional multidisciplinary and interdisciplinary problem-solving frameworks within academia to link together scientists, practitioners, and stakeholders, thereby enabling connections between multiple ways of interpreting the world while enhancing collaboration across traditional knowledge-production boundaries (Figure 1). ${ }^{41} 4243$ Transdisciplinary knowledge production can be an effective tool for engaging all actors in environments where physical, social, technical, and economic sectors interact with culture and values, such as in community-based engineering sustainable design projects. ${ }^{44}$ Transdisciplinary knowledge has the potential to not only address the multifaceted complexities of the engineering design process occurring between multiple stakeholders, but also provide a model for integrating non-technical dimensions into design solutions.

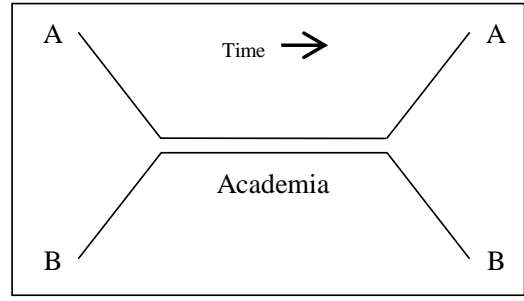

Multidisciplinary

Researchers $(\mathrm{A}, \mathrm{B})$ join together to work on a common problem. Then split apart unchanged when work is finished.

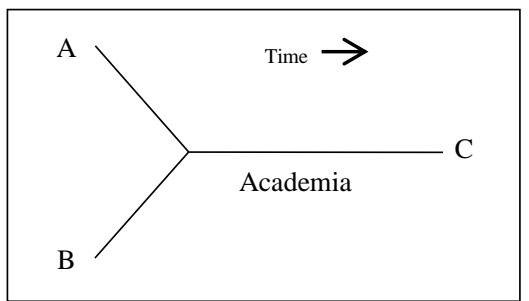

Interdisciplinary

Researchers (A,B) join together to work on a common problem. Interaction may forge a new field or disciplines (C).

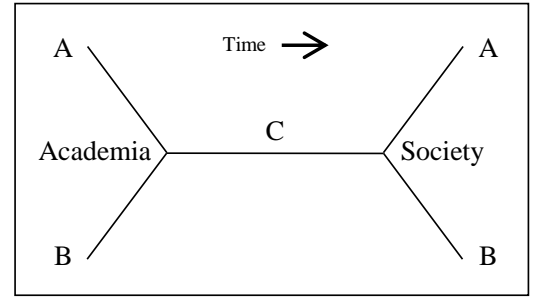

Transdisciplinary

Researchers (A,B) and society members $(\mathrm{D}, \mathrm{E})$ join together to work on a common problem. Interaction creates new, contextspecific knowledge (C).

\section{FIGURE 1}

\section{MULTIDISCIPLINARY, INTERDISCIPLINARY, AND TRANSDISCIPLINARY PROBLEM-SOLVING FRAMEWORKS (MODIFIED FROM BORREGO AND NEWSWANDER ${ }^{46}$ ).}

While there has been work in integrating transdisciplinary knowledge production frameworks into various areas of sustainability and engineering-e.g., groundwater management, energy resources analysis, sustainable supply chain management ${ }^{47} 48 \quad 4950$-efforts have largely been focused upon using these frameworks for research rather than as curricular interventions. Additionally, Remington-Doucette et al. ${ }^{51}$ found that "despite the apparent benefits and widespread advocacy for interdisciplinary and transdisciplinary programs [in higher education], the success of these programs in fostering students' capacities for real-world problem solving 
International Journal for Service Learning in Engineering, Humanitarian Engineering and Social Entrepreneurship

Vol. 13, No. 1, pp. 1-52, Spring 2018

ISSN 1555-9033

remains unsubstantiated." In other words, little work has been done to document and assess transdisciplinary-focused curricular interventions in the classroom setting.

To further complicate matters, the majority of the related literature in engineering education refers to transdisciplinary knowledge as thinking or working across academic disciplines, but excluding knowledge and knowledge production processes outside of academia. ${ }^{52} 53545556$ While research has demonstrated how such approaches can improve the ability of students to integrate diverse perspectives and tools from academic disciplines, potentially relevant perspectives and knowledge production tools from outside of academia often remain marginal or invisible. ${ }^{57} 585960$ As multiple scholars have argued, ${ }^{616263}$ completing the transdisciplinary knowledge production loop requires integration efforts that transcend the academic sphere.

\section{Appropriate Learning Environments}

While transdisciplinary knowledge production models may offer frameworks for problem solving to increase students' awareness of non-technical dimensions of design, specific learning environments are also needed to effectively integrate these dimensions into sustainable design solutions. For instance, Steinemann ${ }^{64}$ calls for education for sustainability that integrates interactive, experiential, transformative, and real-world learning experiences. Scholars suggest that such experiences might include: active learning, cooperative learning, and real-world experiences that offer a valuable service for communities without reducing the academic content. ${ }^{65}$ 66 These experiential, hands-on design experiences can build confidence in engineering design skills. ${ }^{67}$ They can also increase sustainability competencies by linking knowledge with action in problem solving; increasing awareness of values, politics, and resources in negotiated problem solving processes; and providing exposure to meaningful collaboration. ${ }^{68} 69$

Experiential learning strategies, such as problem-/project-based learning (PBL) and servicelearning, have demonstrated success in developing professional engineering competencies. In PBL, students learn about a subject through the experience of solving an authentic, openended problem in ways that encourage and nurture deep, active learning. ${ }^{70} 7172$ For example, Secundo et al. ${ }^{73}$ found that PBL strategies embedded in cooperative partnerships with academia and industry in a manufacturing engineering courses are most suitable for developing engineering competencies, both technical and professional. In computer engineering, students participating in a project-based active and collaborative learning environment similarly demonstrated enhanced teamwork and communication skills. ${ }^{74}$

Service-learning, on the other hand, offers credit-bearing, educational opportunities in which students participate in and reflect upon an organized service activity that meets an identified community need while simultaneously increasing understanding of the academic concepts being taught. ${ }^{75}{ }^{76}$ Using service-learning as a pedagogical strategy in engineering to help prepare students to engage in real world contexts has received increasing attention among educators, ${ }^{77} 787980$ as reflected in a growing number of engineering courses that now include service-learning as a method to increase awareness and understanding of professional skills and other non-technical dimensions of engineering practice, i.e., ABET 3.g, 3.h, and 3.j. 81828384858687

The service-learning model may be a particularly promising approach that is especially wellsuited to promoting competency in integrating non-technical dimensions of sustainability into design solutions. This pedagogical strategy has been shown to promote engagement and collaboration with partners outside of academia. ${ }^{88} 8990$ Further, other scholars have demonstrated 
International Journal for Service Learning in Engineering, Humanitarian Engineering and Social Entrepreneurship

Vol. 13, No. 1, pp. 1-52, Spring 2018

ISSN 1555-9033

that students can develop a deep understanding of the impact of technical engineering solutions in the environmental and societal context, especially by reflecting on their service-learning experiences and recognizing that their efforts will lead to concrete results in the real world. ${ }^{91} 92$ Additionally, Coyle et al. ${ }^{93}$ and Al-Khafaji and Morse ${ }^{94}$ noted the development of non-technical skills, e.g., sustainability awareness, cultural sensitivity, and teamwork, increased after servicelearning experiences. Significant increases in sustainability problem-solving competencies can also occur when using service-learning as a pedagogical tool. For example, Al-Khafaji and Morse ${ }^{95}$ found that service-learning provided opportunities to integrate social and other non-technical dimensions of engineering design into the curriculum, whereas Clevenger and Ozbek ${ }^{96}$ found that service-learning. Additionally, Hayden et al. ${ }^{97}$ observed that service-learning influences students' understanding of the roles and responsibilities of engineers in society.

By combining the two pedagogical strategies-PBL and service-learning-together with a transdisciplinary knowledge production model, this research was designed to directly address the need for engineering students to be able to integrate non-technical dimensions into their community-based design solutions, thus increasing their competencies in sustainability problem solving. Ultimately, this study further advances our understanding of appropriate learning environments and teaching methods, as well as assessment tools for developing such competencies.

\section{METHODS}

To build upon prior research and explore how transdisciplinary learning in community-based design projects, as well as affect their sustainability problem-solving competencies, a case study of teaching and learning in an upper-level environmental and ecological engineering servicelearning community-based design course (EEE 495) was conducted in the spring of 2014. A case study approach is an appropriate research design for such an investigation because: 1) the nature of the research question is typically explanatory, exploratory, or descriptive; 2) the investigator lacks methods to control the site and participants; and 3) the phenomenon being studied is contemporary and the context is real life. ${ }^{98}$ A second, condensed intervention was also conducted in two Engineering Projects in Community Service (EPICS) lecture skill sessions in spring of 2014. EPICS is a service-learning design program in which teams of students partner with local and global community organizations to address human, community, and environmental needs. The lead author taught the course and served as the primary instrument for data collection and analysis with the second author. To increase objectivity and transparency, as well as mitigate against biases in the study the researchers followed appropriate protocol, specifically utilizing a third researcher to conduct the interviews.

The specific research questions that guided this study were:

RQ1: How does a transdisciplinary knowledge production model for decision making affect students' awareness of, understanding of, and ability to apply non-technical dimensions into community-based design projects?

RQ2: How does a transdisciplinary knowledge production model for decision making affect students' sustainability problem-solving competencies? 


\section{Research Context}

Since local environmental issues are inherently linked to multiple dimensions of sustainability and involve a multitude of stakeholders' values, interests, and opinions, they serve as appropriate design opportunities for educators seeking to increase students' professional engineering and sustainability competencies. Additionally, the accessibility of the project site, as well as the opportunity to address an immediate community need in a relatively short time frame, makes it a fitting learning environment for the first of two interventions studied here. The first, a three-credit, semester-long, elective, interdisciplinary environmental and ecological engineering course at a large, Midwestern research-intensive university introduced a specific environmental issue, namely by focusing on an unhealthy local river with stormwater runoff problems, coupled with small-scale best management practices in remediation, i.e., rain gardens, rain barrels, pervious pavement, and native savannas. In partnership with two local non-profits, a local business, and an industry funder, students were tasked with identifying stormwater management issues, designing small-scale technical solutions, maintaining budgets, and evaluating impacts with a local middle school. In this real-world, service-learning context, students were taught about the complex and dynamic relationships between social, economic, environmental, and political dimensions in sustainable community-based design projects, as well as how to use a transdisciplinary knowledge production model in design (Figure 2).

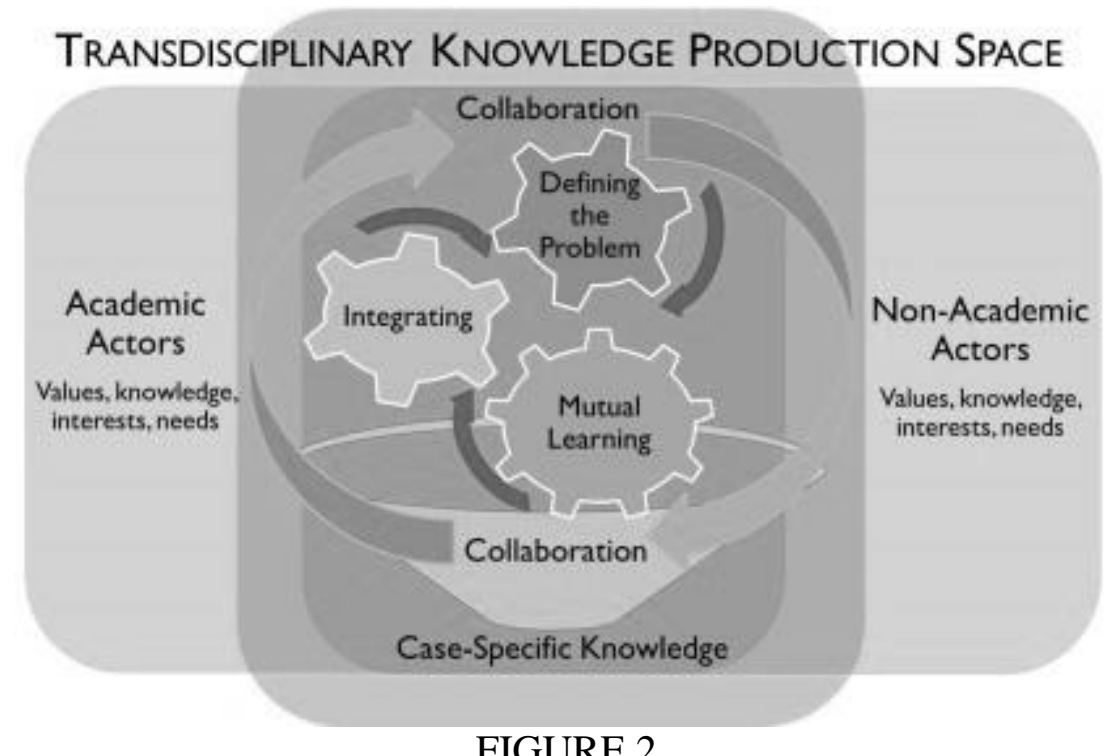

FIGURE 2

TRANSDISCIPLINARY KNOWLEDGE PRODUCTION MODEL FOR SUSTAINABLE COMMUNITY-BASED DESIGN. ${ }^{99}$

The transdisciplinary knowledge production model was developed based upon a literature review analyzing the discourse of transdisciplinary knowledge across academic disciplines in regards to actors and interactions involved in the transdisciplinary knowledge production process. ${ }^{100}$ The specific learning outcomes and objectives for the course were aligned with this framework and research questions (Table 1). Course activities and assessments outlined in the syllabus included: lectures; readings; team facilitation and critical reflection assignments; group 
International Journal for Service Learning in Engineering, Humanitarian Engineering and Social Entrepreneurship

Vol. 13, No. 1, pp. 1-52, Spring 2018

ISSN 1555-9033

presentations and proposals; design charrettes; stakeholder feedback sessions; and self- and peerevaluations. All activities were structured to provide students with opportunities to develop an increased awareness of, understanding of, and ability to apply non-technical dimensions into community-based design projects by using a transdisciplinary knowledge production model for decision making, thus enhancing sustainability problem-solving competencies.

TABLE 1

LEARNING OUTCOMES FOR ENVIRONMENTAL AND ECOLOGICAL ENGINEERING: URBAN WATER PROJECTS (EEE 495) MAPPED TO RESEARCH QUESTIONS.

\section{Learning Outcomes}

Research Questions*

Students will be able to:

1. Design novel, context-appropriate solutions to local stormwater sustainability issues using a transdisciplinary knowledge production model.

a. Describe the interconnectivity between environmental, social, political, and economic issues surrounding technical solutions.

RQ1

b. Apply a transdisciplinary knowledge production model.

RQ1

c. Propose solutions to open-ended design problems that demonstrate a deep comprehension of the issues.

RQ2

Students will be able to:

2. Engage in the complexities of a negotiated design process occurring between multiple stakeholders in a professional and ethical manner.

a. Demonstrate empathy and adaptability in working with teammates and stakeholders with varied skills, talents, abilities, and work strategies.

b. Create project deliverables that demonstrate cohesive stakeholder functionality.

RQ2

c. Critically evaluate personal and others' contributions to the overall success of the projects.

Students will be able to

3. Display social responsibility, civic engagement, and leadership in addressing local water sustainability issues.

\begin{tabular}{llc}
\hline a. & Evaluate and apply diverse perspectives from multiple stakeholders. & RQ1, RQ2 \\
\hline b. & Connect and extend academic knowledge to civic engagement. & -- \\
\hline c. & $\begin{array}{l}\text { Take informed, responsible action to address ethical, social, and } \\
\text { environmental challenges. }\end{array}$ & RQ2 \\
\hline d. & $\begin{array}{l}\text { Communicate project efforts in a creative, well-organized, and logical } \\
\text { manner. }\end{array}$ & -- \\
\hline
\end{tabular}

*Note: the focus of the study design and intervention was on investigating RQ1, then conclusions were drawn relative to RQ2 based upon these results. 
The second intervention, the forty-five minute EPICS skill session, consisted of a short lecture and small group discussion designed to increase participants' awareness and understanding of nontechnical dimensions in community-based design projects. EPICS skills sessions are specialized lecture supplements that provide opportunities for EPICS students to gain expertise needed for projects and broaden their experience. ${ }^{101}$

\section{Participant Demographics}

Fifteen students completed the EEE 495 course representing the following majors: environmental and ecological engineering (12 students), political science (1), natural resources and environmental science (1), and landscape architecture (1). The majority of the students were juniors (10 students), along with three seniors, one sophomore, and one freshman. There were seven participants who identified as female and eight as male. Five of the students reported having some sort of prior design experience; however, none of those experiences involved direct contact with users during all stages of the project, making the design experience in this course very distinct from previous exposure.

A total of twenty-five students completed the two EPICS skill sessions, representing the following majors: agricultural and biological engineering (1 student), agronomy (1), biological engineering (1), chemistry (1), computer engineering (1), electrical and computer engineering (1), electrical engineering (4), first year (4), industrial engineering (1), mechanical engineering (3), mechanical engineering technology (1), statistics (1), and (5) unknown/not specified. Of the students, seven were seniors, four were juniors, six were sophomores, and three were first-year. There were eight participants who self-identified as female and eleven as male. For completing all study procedures, participating students in EEE 495 received 1\% extra credit toward their overall course grade. EPICS student participants satisfied a course requirement by attending the skill session.

\section{Data Collection and Analysis}

Data collection methods were selected to provide multiple sources of evidence for triangulation, or a convergence of results, and a rich description of the intervention. ${ }^{102}{ }^{103}$ As certain methods are appropriate for specific situations, mixing methods can help capitalize on the advantages of both qualitative and quantitative approaches, including by reducing biases associated with overreliance on specific data sources and methods. ${ }^{104} 105$ Using a convergent parallel design in this study, both quantitative and qualitative data were collected and analyzed at the same time. The results were then merged to form an overall interpretation of the educational intervention. Following Yin's ${ }^{106}$ protocol for case study research, a database for data management was developed, as well as documentation of a detailed, complete chain of evidence available for review by external observers.

All quantitative data was collected and subjected to statistical analyses when appropriate, whereas the qualitative data was transcribed, coded, and analyzed to identify common themes and draw inferences, and lastly subjected to statistical analyses when appropriate. To interpret the raw material for the qualitative data, thematic analysis was used to inductively transform qualitative information into quantitative data. ${ }^{107}$ Emergent themes were identified and then all data was 
recoded and grouped according to the dominant themes. Following standard open-coding procedures, a detailed code book and inter-raters were used to verify results. ${ }^{108}$

It is additionally important to note that the intent of this study is to form a unique interpretation of events, not to generalize findings. The uniqueness of the specific context in which the study is occurring mitigates against replicating the intervention and study in exactly the same context; however, transferability and replication in other settings is potentially enhanced through transparency in describing central assumptions, selection of the informants, and the biases and values of researcher. As $\mathrm{Yin}^{109}$ recommends, we also report detailed protocols for data collection. ${ }^{110}$ Appropriate permission for conducting this study was approved by Purdue University's Institutional Review Board (protocol \#1312014361), and all names and institutions referenced in the manuscript are pseudonyms to protect participants' identities.

\section{Data Collection Instruments}

Assessment instruments used in traditional educational settings often include the evaluation of student work, rubrics for learning objectives, and surveys; ${ }^{111}$ however, these data sources are often unsuitable for experiential learning as students need to time to reflect on and think deeply about their experiences. ${ }^{112}$ Service-learning scholars additionally suggest critical reflection, observation, interviews, cumulative portfolios, and post-experience surveys to address this issue. ${ }^{113} 114$ Table 2 provides a summary of the data collection instruments used in this study and associated analysis approaches, and the text below provides an expanded description of each instrument and specific areas of measurement. Data collection instruments were developed based upon an earlier offering of the course in spring 2013 and previous assessment work by Jesiek and Woo ${ }^{115}$ and Jesiek, Haller, and Thompson. ${ }^{116}$ Instruments were piloted among content experts and former students in the course and revised for clarification via a series of iterative feedback and discussion sessions.

TABLE 2

SUMMARY OF DATA COLLECTION INSTRUMENTS, ASSOCIATED DATA, ANALYSIS APPROACH, AND SUBJECTS (SEE APPENDICES A, B, \& C FOR COMPLETE INSTRUMENTS).

\begin{tabular}{llll}
\hline Instrument & Data & Analysis Approach & Subjects \\
$\begin{array}{l}\text { Pre/Post } \\
\text { Interviews }\end{array}$ & Semi-structured & Thematic analysis & $\begin{array}{l}\text { EEE 495 Students } \\
(\mathrm{N}=5)\end{array}$ \\
\hline
\end{tabular}

Forced-response and open-ended

Pre/Post questions addressing students'

Assessment

Survey awareness, understanding, and ability to apply non-technical dimensions and transdisciplinary knowledge production models
EEE 495 Students

Thematic analysis $\quad(\mathrm{N}=15)$

Statistical tests EPICS Students

$(\mathrm{N}=25)$ 


\begin{tabular}{llll} 
& $\begin{array}{l}\text { Semi-structured open-ended questions } \\
\text { addressing students' awareness, } \\
\text { Pre/Post }\end{array}$ & & \\
Reflection & $\begin{array}{l}\text { nden-tanding, and ability to apply } \\
\text { non-techical dimensions and } \\
\text { transdisciplinary knowledge } \\
\text { production models }\end{array}$ & Thematic analysis & $\begin{array}{l}\text { EEE 495 Students } \\
(\mathrm{N}=15)\end{array}$ \\
\hline
\end{tabular}

Interviews

The use of semi-structured interviews (Appendix A) offers a method for pursuing a consistent line of inquiry among participants, while also allowing the interviewer to probe more deeply, seek clarification of respondent's interpretations, and corroborate findings from other data collection instruments. ${ }^{117} 118$ For this study, interview participants were selected from the EEE 495 course based upon their performance on a pre-course assessment survey, e.g., by examining how many non-technical dimensions each student was able to identify in response to a pre-course survey prompt. One high-performing male, two high-performing females, two low-performing males, and one low-performing female were selected to represent multiple viewpoints of the study population. Pre/post interviews were conducted with all six participants; however, one high-performing female did not participate in her post-course interview, and thus her results are not represented in the final analysis. The raw data from the interviews was thematically analyzed for considerations included in the design process with a 90\% agreement in inter-rater reliability using Cohen's kappa, and then recoded using a rubric adapted from Mazzurco, Huff, and Jesiek, ${ }^{119}$ which includes four categories of considerations: stakeholder considerations, technical considerations, non-technical constraints, and broader considerations (Figure 3 ).

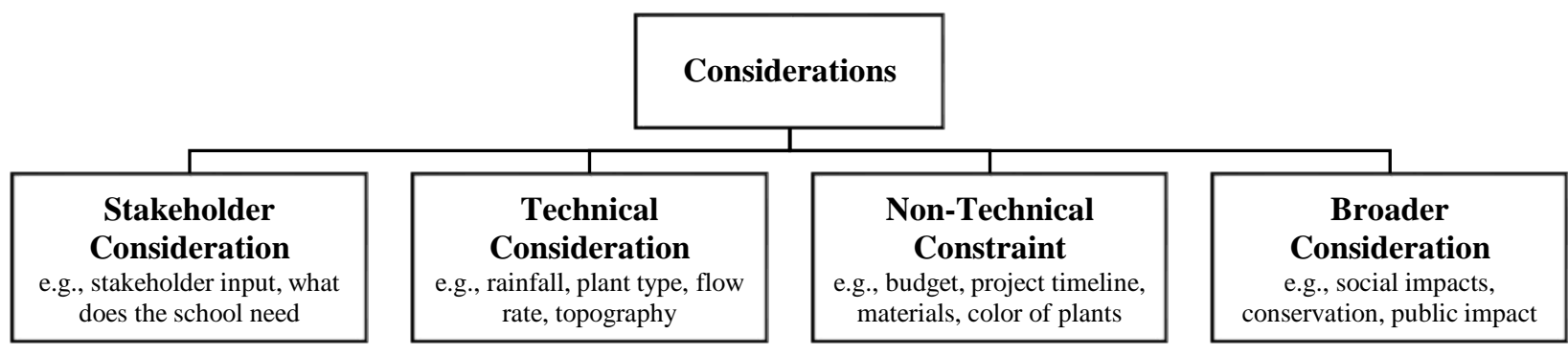

FIGURE 3

\section{CODING HIERARCHY FOR CONSIDERATIONS WITH EXAMPLE CODED ITEMS (ADAPTED FROM MAZZURCO, HUFF, AND JESIEK ${ }^{120}$ ).}

Coding for design considerations was intended to measure awareness of, understanding of, and ability to apply non-technical dimensions to community-based design projects. Thematic analysis was also used to inductively code the raw data for actors and interactions involved in the knowledge production process with respective agreements in inter-rater reliability of $94 \%$ and $87 \%$. Since the final rubrics used to recode the raw data emerged during the data analysis, they will be discussed in more detail in the results section. Coding for actors and interactions measures 
awareness, understanding, and ability to apply a transdisciplinary knowledge production model in community-based design projects. Coding for actors provided insight into individuals that are included and/or excluded in transdisciplinary knowledge production, whereas coding for interactions offered an overview of processes and methods used by students in transdisciplinary knowledge production. Descriptions of each overarching construct and an excerpt of coded text for each measure are listed below in Table 3.

TABLE 3

DESCRIPTIONS OF EACH OVERARCHING CODE FOR EACH CONSTRUCT AND AN EXCERPT OF CODED TEXT FOR EACH MEASURE FROM INTERVIEW DATA.*

\section{Considerations}

Definition

Includes items, things, considerations (stakeholder, technical, nontechnical, broader) to be thought about or considered during the design process

Example excerpt “...you have to consider people, investors, you have to consider schools, used for coding kids, their wants, needs. You have to consider the natural aspect of where "considerations" you are trying to implement these designs and how it is going to affect the landscape and how much we will conserve."

\section{Actors}

Definition

Includes individuals/groups involved in knowledge production and decision making through actionable engagement, i.e. questioning, collaborating, designing

Example excerpt used for coding "actors"
"Us in academia that includes the students and the instructors. You have professional engineers, contractors, people who actually do this work out in the field. Teachers and students at the school and maintenance workers, people at the building who are directly affected. People who are indirectly affected, people who drive by, the parents, the English teachers who see it but are not going to teach their kids about is necessarily."

\section{Interactions}

Definition

includes an action or process involved in knowledge production or toward the achievement of transdisciplinary knowledge

Example excerpt used for coding "interactions"
"... communication, talking, physically talking, whatever method of communication you get to actually interact with the other stakeholders involved. That is the biggest one. Just really openness, the willingness to offer feedback to share opinions to think collaboratively with other people."

\footnotetext{
*Underlined instances designate coded text.
} 


\section{Assessment Surveys}

The assessment survey (Appendix B) included an open-ended, rank order scenario prompt (questions \#2-3) and two forced-choice response, rank-order prompts (\#4, 12) for design considerations, as well as Likert scale measures (\#5-11, 13-19) for understanding of the transdisciplinary knowledge production model and associated actors and interactions involved. All fifteen students in the EEE 495 course, as well as twenty-five EPICS students, completed both the pre- and post-course intervention assessment surveys. Pre/post-course mean scores were calculated for all quantitative questions, and qualitative questions were thematically analyzed for considerations included in the design process with a $90 \%$ agreement in inter-rater reliability. (Items $\# 11,14,16,18$, and 19 were excluded from analysis as they were ineffective measures, e.g., preassessment ratings were very high to begin with and/or did not change.) Coding for design considerations measures awareness of, understanding of, and ability to apply non-technical dimensions to community-based design. Whereas, analyzing the data for actors and interactions measures awareness of, understanding of, and ability to apply transdisciplinary knowledge production models in community-based design, as well as participant's awareness, understanding, and ability to apply non-technical dimensions to community-based design.

\section{Reflections}

Critical reflection can generate, deepen, and document learning, and can therefore serve as an effective tool to measure learning outcomes in service-learning and other educational settings. ${ }^{121}$ 122 The two reflection exercises (Appendix C) used in this study were class assignments seeking to measure students' awareness of, understanding of, and ability to apply transdisciplinary knowledge production models in community-based design. All fifteen students in the EEE 495 course completed both reflections, which were conducted in the third and tenth weeks of the course. The raw data from the reflections was thematically analyzed for actors and interactions involved in the knowledge production process with $94 \%$ and $87 \%$ agreements in inter-rater reliability, respectively.

\section{FINDINGS}

\section{EEE 495 Results}

The subsequent sections present the results of the previously mentioned assessments (interviews, assessment survey, and reflections) and their contributions to increasing students' awareness of, understanding of, and ability to apply non-technical dimensions and a transdisciplinary knowledge production model in community-based design projects. All results are students' self-reported perceptions, and are organized by the following three constructs: considerations, actors, and interactions. The construct considerations was selected as it includes items and things to be thought about or considered during the design process, thus highlighting students' awareness of, understanding of, and ability to apply non-technical dimensions to design. The construct actors provides insight into students' awareness and understanding of individuals that are included and/or excluded in the transdisciplinary knowledge production model in community-based design projects. The construct interactions offers insights regarding students' awareness and 
understanding of approaches, processes, and methods included and/or excluded in the transdisciplinary knowledge production model in community-based design projects. The majority of the results presented are from the EEE 495 intervention; however, a few samples of the EPICS skill session results are also highlighted at the end of the results section.

\section{Considerations}

Analysis of the qualitative and quantitative data from the interviews and assessment surveys showed increased student awareness of stakeholder considerations. In the interview data more specifically, stakeholder considerations accounted for 40\% (32 of 80) of the coded responses in the pre-course interview versus $44 \%$ (35 of 80) in the post-course interview (Figure 4).

\section{Interview Frequency Counts and Associated Percentages}

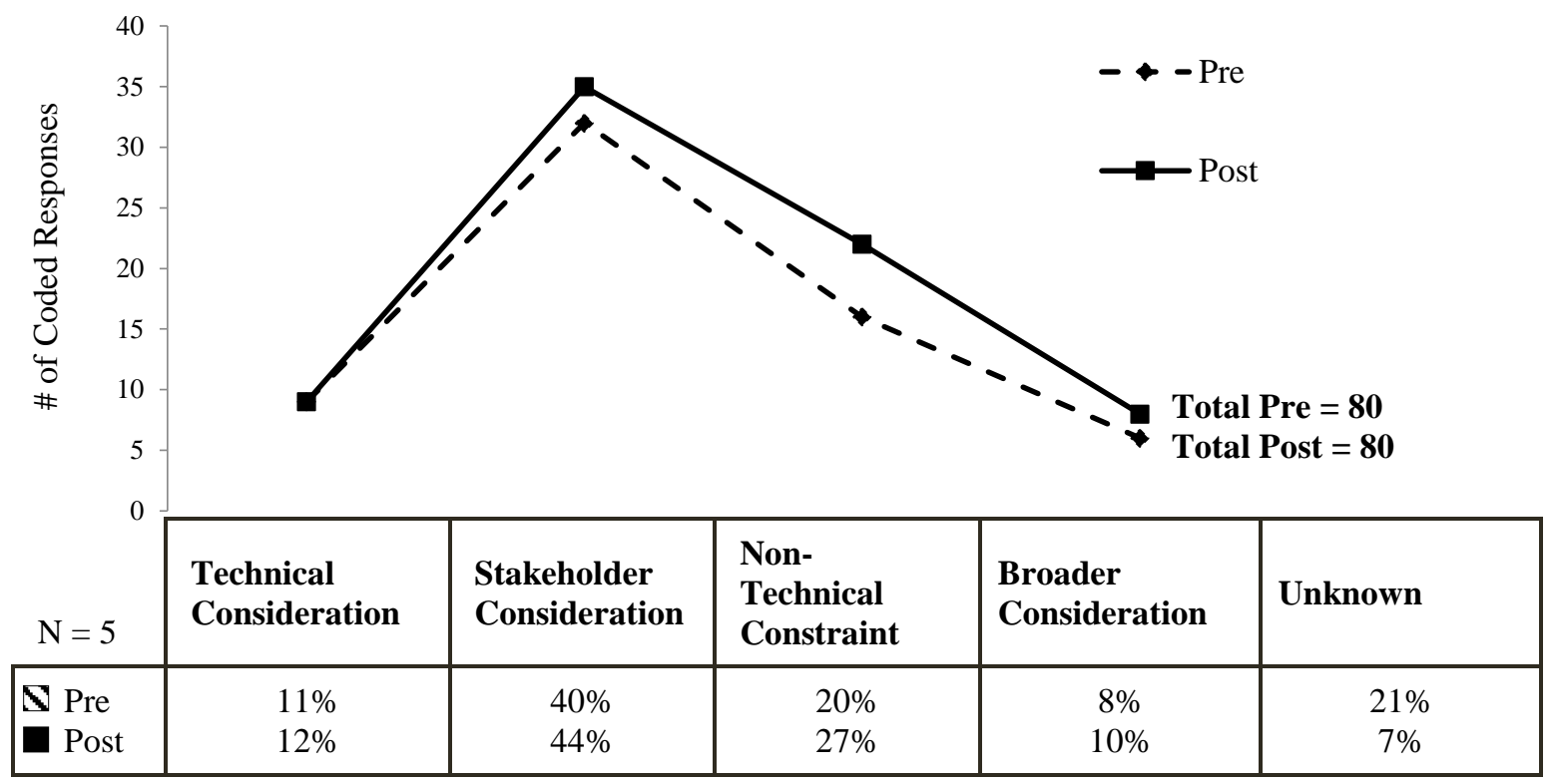

FIGURE 4

PRE/POST INTERVIEW FREQUENCY COUNTS OF CODED CONSIDERATIONS AND ASSOCIATED PERCENTAGES.

Even more notably, in the EEE 495 assessment survey data, stakeholder considerations increased from $13 \%$ (10 of 78) of the coded responses in the pre-course assessment survey to $31 \%$ (23 of 75) in the post-course assessment survey (Figure 5). 


\section{Assessment Survey (Question 2) Frequency Counts and Associated Percentages}

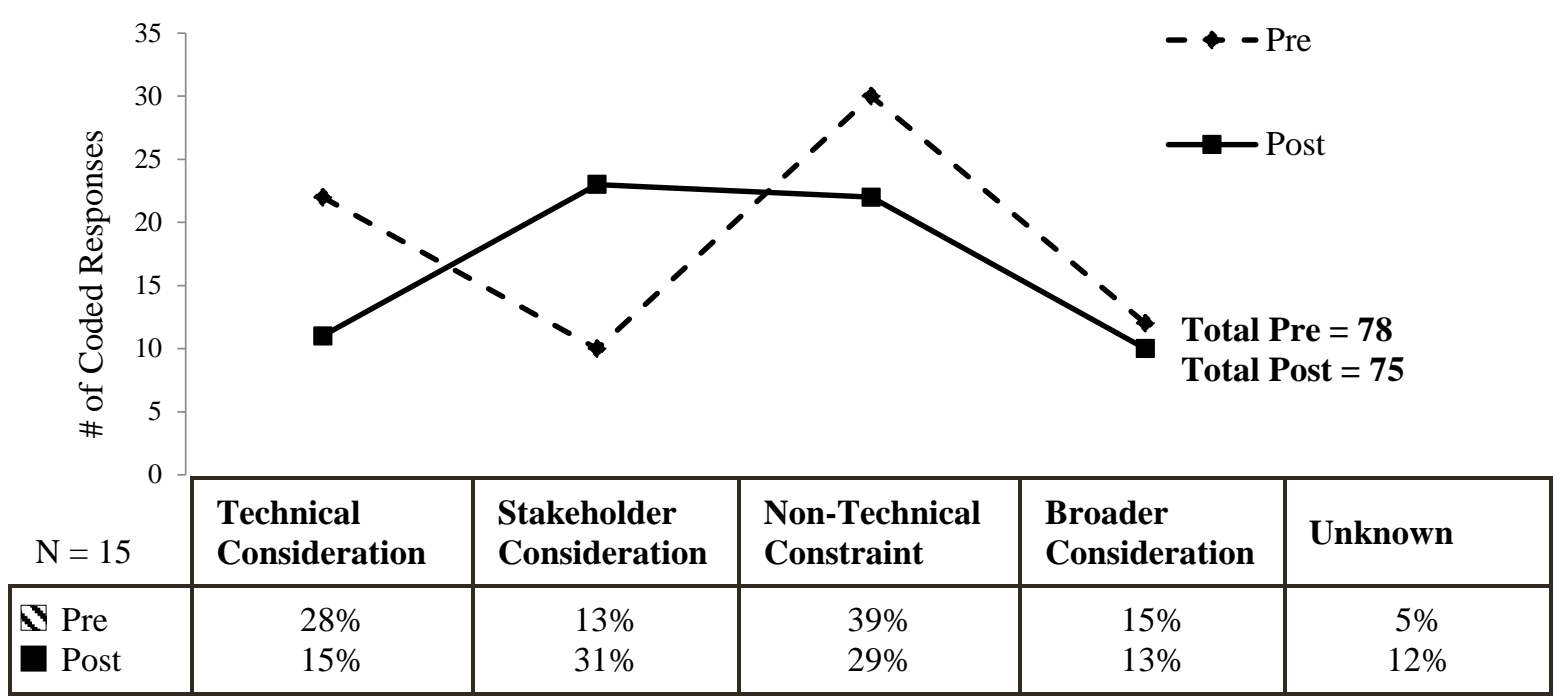

FIGURE 5

PRE/POST ASSESSMENT SURVEY FREQUENCY COUNTS OF CODED CONSIDERATIONS AND ASSOCIATED PERCENTAGES.

Statistical analysis of the assessment survey data also provides evidence that there are significant differences between pre/post-course frequencies in mentions of stakeholder considerations (Table 4).

TABLE 4

NUMBER OF CODED RESPONSES FOR CONSIDERATIONS IN PRE/POST INTERVIEWS AND PRE/POST ASSESSMENT SURVEY QUESTION \#2 AND ASSOCIATED STATISTICAL SIGNIFICANCE.

\begin{tabular}{|c|c|c|c|c|c|c|c|c|c|}
\hline \multirow[t]{2}{*}{ Consideration } & \multicolumn{2}{|c|}{$\begin{array}{l}\text { Interviews, } \\
\mathbf{N}=\mathbf{5}\end{array}$} & \multirow[t]{2}{*}{$\begin{array}{c}\text { Paired } \\
\text { T-Test } \\
\text { (p-value) }\end{array}$} & \multicolumn{2}{|c|}{$\begin{array}{l}\text { Assessment } \\
\text { Survey (Q2) } \\
\text { EEE 495, } \\
\mathbf{N}=15\end{array}$} & \multirow[t]{2}{*}{$\begin{array}{c}\text { Paired } \\
\text { T-Test } \\
\text { (p-value) }\end{array}$} & \multicolumn{2}{|c|}{$\begin{array}{l}\text { Assessment } \\
\text { Survey (Q2) } \\
\text { EPICS, } \\
\mathbf{N}=25\end{array}$} & \multirow[t]{2}{*}{$\begin{array}{c}\text { Paired } \\
\text { T-Test } \\
\text { (p-value) }\end{array}$} \\
\hline & Pre & Post & & Pre & Post & & Pre & Post & \\
\hline $\begin{array}{l}\text { Technical } \\
\text { Consideration }\end{array}$ & 9 & 9 & 1.000 & 22 & 11 & $0.022^{*}$ & 14 & 5 & $0.047^{*}$ \\
\hline $\begin{array}{l}\text { Stakeholder } \\
\text { Consideration }\end{array}$ & 32 & 35 & 0.753 & 10 & 23 & $0.003 * *$ & 29 & 39 & $0.030^{*}$ \\
\hline $\begin{array}{l}\text { Non-Technical } \\
\text { Constraint }\end{array}$ & 16 & 22 & 0.547 & 30 & 22 & 0.164 & 37 & 40 & 0.559 \\
\hline $\begin{array}{l}\text { Broader } \\
\text { Consideration }\end{array}$ & 6 & 8 & 0.541 & 12 & 10 & 0.546 & 16 & 15 & 0.628 \\
\hline Total & 63 & 74 & 0.180 & 74 & 66 & $0.041 *$ & 96 & 99 & 0.612 \\
\hline
\end{tabular}

*significant at $\mathrm{p}$-value $<0.05, * *$ significant at $\mathrm{p}$-value $<0.01$ 
Additionally, the following excerpts from one subject highlight an example of the increase in stakeholder considerations in pre/post-course interview responses. Coded stakeholder considerations are underlined. In the pre-course interview response excerpt, stakeholder considerations are not mentioned, whereas in the post-course interview response excerpt they are mentioned three times.

\section{Interview Question Prompt}

In this course you have participated in a community-based design project. What types of knowledge or design concerns did you incorporate into your project?

Pre-Course Interview Response

"Budgetary constraints, all of the physical constraints, and then the time to get it done."

Post-Course Interview Response

"The most important is satisfying the stakeholders' needs and wants. Whatever the stakeholders identified as important for whatever reason, we valued it as important. If we deliver a project that ignores all of their requests and they don't ever use it or it never gets actually completed then that defeats the purpose of the whole thing. Any concern or issue the stakeholders brought to the table was treated as important and addressed as such."

Similar patterns emerge in the assessment survey results in the forced response, rank order questions, specifically in the first question regarding the kinds of information needed in designing a rain garden at a local science museum (\#4). Of the thirteen forced responses included, four of them had a stronger stakeholder dimensionality (handicapped accessibility, input from museum curator, neighborhood/user opinion, and safety), hence they were more desirable in terms of transdisciplinary understanding. There were significant differences in the ranking of importance between pre/post-course frequencies in input from museum curator and neighborhood/user opinion in the EEE 495 data $(<0.01$ and 0.004) (Table 5). As these items represent people directlyimpacted by the design, and not just ideas related to people, i.e., handicapped accessibility, the significance in the selection of these items suggests a more nuanced understanding of differing levels of stakeholder consideration in the context in which the design is occurring. 
International Journal for Service Learning in Engineering, Humanitarian Engineering and Social Entrepreneurship

Vol. 13, No. 1, pp. 1-52, Spring 2018

ISSN 1555-9033

TABLE 5

STUDENT PRE/POST-COURSE ASSESSMENT SURVEY RESULTS FOR A FORCED RESPONSE, RANK ORDER QUESTION REGARDING THE KINDS OF INFORMATION NEEDED IN DESIGNING A RAIN GARDEN AT A LOCAL SCIENCE MUSEUM.

\section{Assessment Survey (Q4)}

You have been asked to design a rain garden at a local science museum. You have a limited amount of time and resources to gather information that will be used throughout the duration of the design project. From the following list, RANK ORDER the kinds of information you would MOST LIKELY NEED as you work on your design.

(1 = most important, 13 = least important $)$

\begin{tabular}{|c|c|c|c|c|c|c|}
\hline & \multicolumn{2}{|c|}{$\begin{array}{l}\text { Mean Rank } \\
\text { EEE 495, N = } 15\end{array}$} & \multirow{2}{*}{$\begin{array}{c}\text { Paired } \\
\text { T-Test } \\
\text { (p-value) }\end{array}$} & \multicolumn{2}{|c|}{$\begin{array}{l}\text { Mean Rank } \\
\text { EPICS, N = 25 }\end{array}$} & \multirow{2}{*}{$\begin{array}{c}\text { Paired } \\
\text { T-Test } \\
\text { (p-value) }\end{array}$} \\
\hline & Pre & Post & & Pre & Post & \\
\hline Handicapped Accessibility & 9.8 & 10.4 & 0.279 & 9.0 & 8.8 & 0.504 \\
\hline Input from museum curator & 7.1 & 3.8 & $<0.01^{* *}$ & 6.1 & 4.7 & $0.040^{*}$ \\
\hline Neighborhood/user opinions & 6.6 & 3.3 & $0.004 * *$ & 8.3 & 5.0 & $<0.01 * *$ \\
\hline Safety & 5.4 & 6.8 & 0.865 & 4.0 & 3.5 & 0.418 \\
\hline
\end{tabular}

*significant at p-value $<0.05, * *$ significant at $\mathrm{p}$-value $<0.01$

In the second forced response, rank order question, regarding the relative importance of including each type of knowledge source, the choice of stakeholders/users directly involved as most important in relation to six other knowledge sources (i.e., general public, academics, nonacademics, field engineers/scientists, policymakers/politicians, contractors) occurred more frequently in the post-course survey results. These results, however, were not at a significant level (see Appendix B for survey instrument).

Results from the construct considerations in the EPICS data set demonstrate similar patterns to the EEE 495 intervention regarding an increased awareness for and understanding of nontechnical dimensions in community-based design projects. There are significant differences between pre/post-intervention frequencies of stakeholder considerations in assessment survey questions two and three (Table 4), as well as in assessment survey question four regarding input from museum curator and neighborhood/user opinion (Table 5). These findings suggest that simply having engaged discussions with students may be enough to at least heighten their awareness of stakeholder considerations, but perhaps may not be sufficient enough in increasing students' abilities to apply non-technical dimensions in community-based design projects.

Ultimately, the evidence presented across instruments for the construct considerations provides evidence of increased student awareness and understanding of stakeholder involvement in community-based design projects, i.e., non-technical dimensions. It also suggests that a transdisciplinary knowledge production model may enhance students' abilities to integrate nontechnical dimensions in community-based design projects, thus increasing sustainability problemsolving competencies. 
International Journal for Service Learning in Engineering, Humanitarian Engineering and Social Entrepreneurship

Vol. 13, No. 1, pp. 1-52, Spring 2018

ISSN 1555-9033

\section{Actors}

A coding rubric for the construct actors involved in transdisciplinary knowledge production for community-based design projects emerged from thematic analysis of the qualitative interview and reflection data. Using the rubric below (Figure 6), actors were sorted into two categories designating them as academics or non-academics. Academic and non-academic actors were then categorized based upon their association with the project at the focus of this study, i.e., directlyor indirectly-impacted.

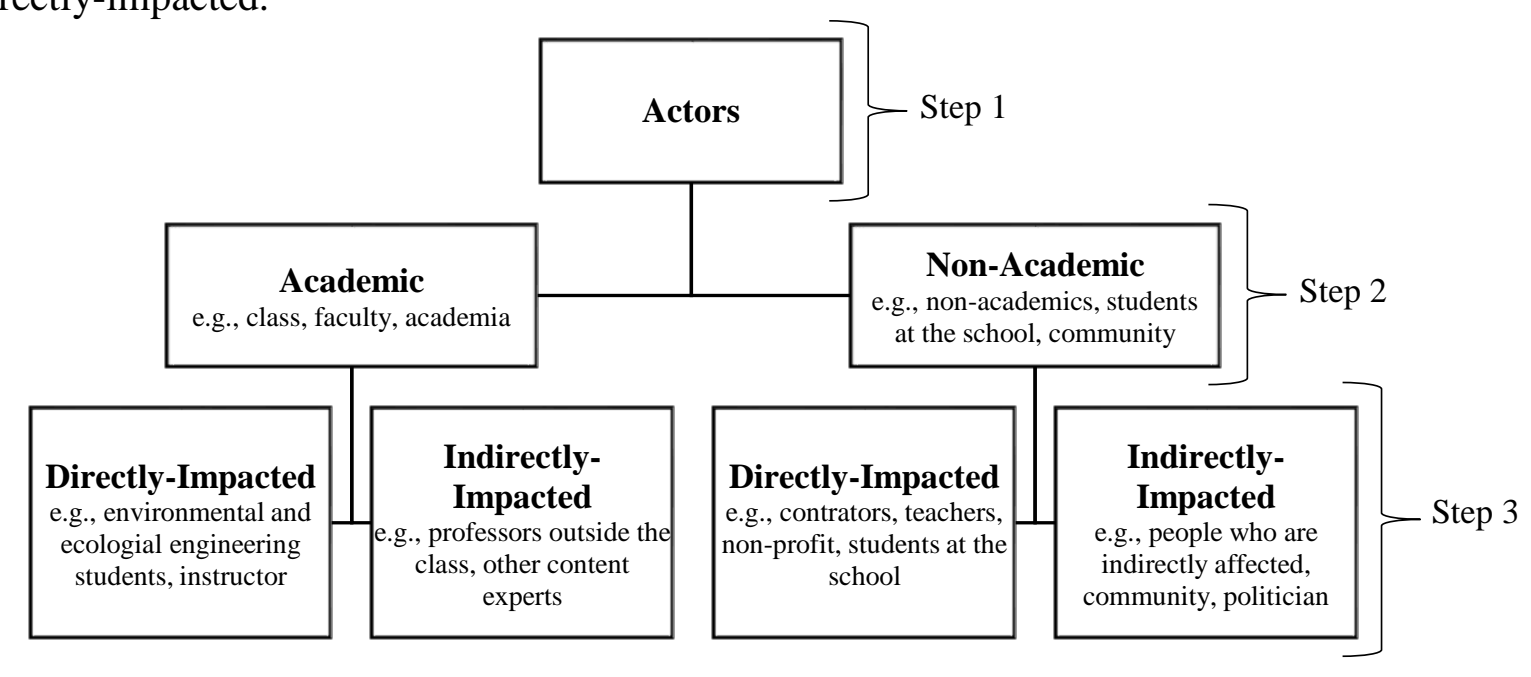

FIGURE 6

CODING PROCEDURES AND A HIERARCHY FOR ACTORS INVOLVED IN TRANSDISCIPLINARY KNOWLEDGE PRODUCTION.

When viewing the coded responses categorically, clear patterns emerge. Due to the intervention, as expected, the raw number of total coded actors increased from the first to second sets of interview and reflection data. Specifically, in the non-academic and directly-impacted categories, increases were statistically significant demonstrating greater depth and sophistication in understanding of the design context and relationship among the actors involved (Table 6). 
International Journal for Service Learning in Engineering, Humanitarian Engineering and Social Entrepreneurship

Vol. 13, No. 1, pp. 1-52, Spring 2018

ISSN 1555-9033

TABLE 6

NUMBER OF CODED RESPONSES FOR ACTORS INVOLVED IN TRANSDISCIPLINARY KNOWLEDGE PRODUCTION IN COMMUNITY-BASED DESIGN PROJECTS IN INTERVIEW AND REFLECTION DATA FROM EEE 495 STUDENTS WITH ASSOCIATED STATISTICAL SIGNIFICANCE

\begin{tabular}{|c|c|c|c|c|c|c|}
\hline \multirow[t]{2}{*}{ Actors } & \multicolumn{2}{|c|}{$\begin{array}{l}\text { Interviews, } \\
\mathbf{N}=\mathbf{5}\end{array}$} & \multirow{2}{*}{$\begin{array}{c}\text { Paired T-Test } \\
\text { (p-value) }\end{array}$} & \multicolumn{2}{|c|}{$\begin{array}{l}\text { Reflection, } \\
\mathrm{N}=15\end{array}$} & \multirow{2}{*}{$\begin{array}{c}\text { Paired T-Test } \\
\text { (p-value) }\end{array}$} \\
\hline & Pre & Post & & Pre & Post & \\
\hline Academics & 25 & 26 & 0.944 & 98 & 163 & $0.002^{* *}$ \\
\hline Non-Academics & 65 & 120 & $0.032 *$ & 164 & 249 & 0.096 \\
\hline Directly-Impacted & 59 & 122 & $0.039^{*}$ & 166 & 352 & $0.002^{* *}$ \\
\hline Indirectly-Impacted & 26 & 19 & 0.515 & 65 & 50 & 0.408 \\
\hline Totals & 175 & 287 & 0.112 & 493 & 814 & $0.010 *$ \\
\hline
\end{tabular}

*significant at $\mathrm{p}$-value $<0.05, * *$ significant at $\mathrm{p}$-value $<0.01$

The excerpts below from one participant highlight the increased depth and sophistication of responses between the two sets of reflection data. Coded non-academic, directly-impacted actors are underlined. This example highlights significantly more mentions of non-academics in the second reflection.

First Reflection Response

"The necessary actors involved in the development of transdisciplinary knowledge will vary from project to project. In general, each project may be broken down into multiple facets. There should be a team member that specializes in each of the facets. For instance, a project may require a technical specialist, a policy specialist, a non-technical scientific specialist, a design specialist, etc."

Second Reflection Response

"We are all very different, yet have similar goals and needs/desires for the project. We are the River University student team, but we are also working with the Johnson students, Urban Landscapers (contractors), Tree City, River Stewards, The Water Foundation, The Johnson School Corporation, and The City of Johnsonville. Each group has something important to contribute including design work, installation labor, professional expertise, funding, publicity, and use of the project. The project would not be the same, and may not be successful, without collaboration between all parties, and an integration of each area of expertise. Aside from the variety of major stakeholders included, there is also great variety in the background of the River University student team. We come from different majors including environmental engineering, natural resources and environmental science, political science, and landscape architecture and design. This variety has given us the tools necessary to comprehensively assess the problem and find a solution. It has been an incredible learning experience, but has not been an easy road." 
Across both instruments, the data provides evidence that there are significant differences over time in frequencies of students referring to directly-impacted actors. A slight increase in understanding of actors involved in transdisciplinary knowledge production also occurred in the assessment survey results in the Likert scale questions although these results were not statistically significant (\#13,15, and 17) (Table 7).

TABLE 7

STUDENT PRE/POST ASSESSMENT SURVEY RESULTS FOR QUESTIONS 13, 15, AND 17 REGARDING UNDERSTANDING OF ACTORS INVOLVED IN TRANSDISCIPLINARY KNOWLEDGE PRODUCTION IN COMMUNITY-BASED DESIGN PROJECTS.

\section{Assessment Survey (Q13, 15 \& 17)}

For questions 13-19, please circle the number that best represents your perceptions.

$(1=$ strongly disagree, 5 = strongly agree $)$

\begin{tabular}{lcc}
\hline & \multicolumn{2}{l}{ Mean Rank } \\
\cline { 2 - 2 } & EEE 495, N 15 \\
\hline $\begin{array}{l}\text { It is important to incorporate information from multiple participants } \\
\text { (scientists, academics, stakeholders, general public) in the community- }\end{array}$ & \multicolumn{2}{c}{ Post } \\
based design process & 5 \\
$\begin{array}{l}\text { Considering local context (i.e., current uses of the project site, opinions of } \\
\text { those affected by the projects, etc.) during the design process is important. }\end{array}$ & 5.7 \\
$\begin{array}{l}\text { Academics and non-academics should collaborate to create } \\
\text { transdisciplinary knowledge for community-based designed projects. }\end{array}$ & 5.6 \\
\hline
\end{tabular}

The evidence presented across instruments for the construct actors provides support for an increased awareness and understanding of the need to include directly-impacted, non-academic actors in community-based design projects. It also suggests that a transdisciplinary knowledge production model may enhance students' abilities to integrate non-technical dimensions in community-based design projects, thus increasing sustainability problem-solving competencies.

\section{Interactions}

A coding rubric for the construct interactions involved in transdisciplinary knowledge production for community-based design projects also emerged from thematic analysis of the qualitative interview and reflection data. Segments of text discussing strings of connected interactions were identified, and then specific interactions were extracted from the excerpt and coded into five emerging categories: collaborating, defining the problem, integrating, mutual learning, and emerging knowledge (see Figure 7 for definitions of each interaction). 
International Journal for Service Learning in Engineering, Humanitarian Engineering and Social Entrepreneurship

Vol. 13, No. 1, pp. 1-52, Spring 2018

ISSN 1555-9033

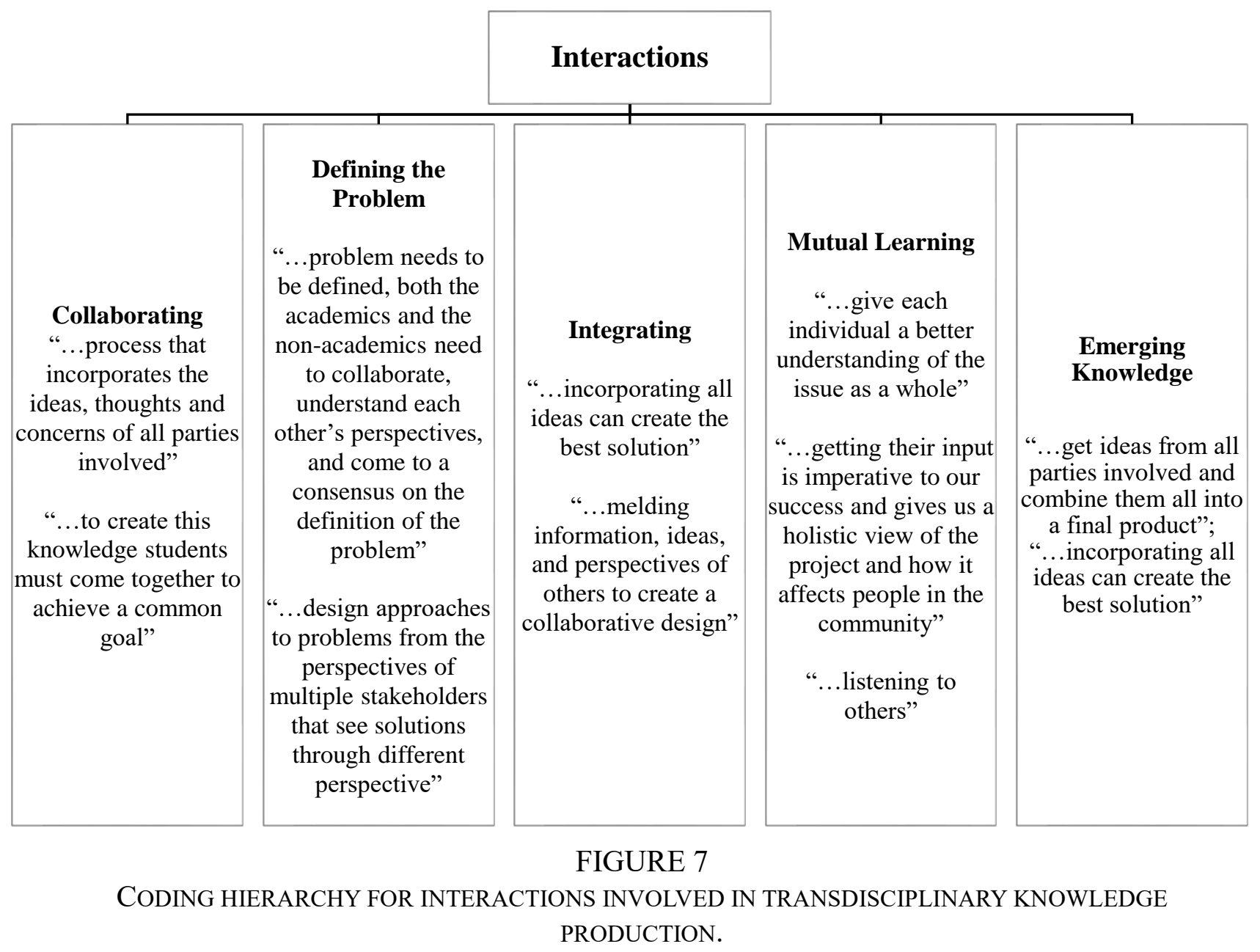

Co-occurring interactions within the segments of text also emerged. Table 8 displays the top five patterns of interactions for the interview and second reflection data sets. The excerpts below from one participant highlight an example of interactions mentioned in the reflection data. Coded interactions and associated patterns are designated by underlining.

Reflection Response Representing the Pattern: "Collaborating” (C)

"For this type of knowledge to emerge, a variety of players can be involved in the discussion about a particular project, practice, or concept."

Reflection Response Representing the Pattern: "Collaborating, defining the problem, integrating, mutual learning, and emerging knowledge" (CDIME)

"It is, therefore, important to collaborate on all aspects of the design and idea creating process. When a problem needs to be defined, both the academics and the non-academics need to collaborate, understand each other's perspectives, and come to a consensus on the definition of the problem. Both groups will see the problem with a different perspective as well as the solution. As both perspectives come together, a higher knowledge is achieved as well as a more effective outcome. The outcome produced and 
International Journal for Service Learning in Engineering, Humanitarian Engineering and Social Entrepreneurship

Vol. 13, No. 1, pp. 1-52, Spring 2018

ISSN 1555-9033

the knowledge gained with will be more useful and effective because the perspective on all of the processes has been broadened."

TABLE 8

NUMBER OF CODED RESPONSES FOR TOP FIVE INTERACTION PATTERNS INVOLVED IN TRANSDISCIPLINARY KNOWLEDGE PRODUCTION IN COMMUNITY-BASED DESIGN PROJECTS IN PRE/POST INTERVIEW AND REFLECTION DATA FROM EEE 495 STUDENTS WITH ASSOCIATED STATISTICAL SIGNIFICANCE.

\begin{tabular}{|c|c|c|c|c|c|c|}
\hline \multirow[t]{2}{*}{ Interaction Patterns } & \multicolumn{2}{|c|}{$\begin{array}{l}\text { Interviews, } \\
\mathbf{N}=5\end{array}$} & \multirow{2}{*}{$\begin{array}{c}\text { Paired } \\
\text { T-Test } \\
\text { (p-value) } \\
\end{array}$} & \multicolumn{2}{|c|}{$\begin{array}{l}\text { Reflection, } \\
N=15\end{array}$} & \multirow{2}{*}{$\begin{array}{c}\text { Paired } \\
\text { T-Test } \\
\text { (p-value) }\end{array}$} \\
\hline & Pre & Post & & First & Second & \\
\hline Collaborating (C) & 4 & 3 & 0.749 & 5 & 20 & $0.002^{* *}$ \\
\hline Integrating $(\mathrm{I})^{\mathrm{a}}$ & 4 & 0 & $0.016^{*}$ & -- & -- & -- \\
\hline Collaborating and Integrating $(\mathrm{CI})^{\mathrm{a}}$ & 1 & 4 & 0.208 & -- & -- & -- \\
\hline $\begin{array}{l}\text { Collaborating \& Mutual Learning } \\
(\mathrm{CM})^{\mathrm{b}}\end{array}$ & -- & -- & -- & 13 & 4 & 0.308 \\
\hline $\begin{array}{l}\text { Collaborating, Integrating, } \quad \& \\
\text { Emerging Knowledge (CIE) })^{b}\end{array}$ & -- & -- & -- & 3 & 7 & 0.164 \\
\hline $\begin{array}{l}\text { Collaborating, Integrating, \& } \\
\text { Mutual Learning (CIM) }\end{array}$ & 2 & 5 & 0.374 & 8 & 6 & 0.433 \\
\hline $\begin{array}{l}\text { Collaborating, Integrating, Mutual } \\
\text { Learning, \& Emerging Knowledge } \\
\text { (CIME) }\end{array}$ & 3 & 4 & 0.704 & 11 & 12 & 0.827 \\
\hline Totals & 14 & 16 & 0.778 & 40 & 49 & 0.672 \\
\hline
\end{tabular}

*significant at p-value $<0.05, * *$ significant at $\mathrm{p}$-value $<0.01$

${ }^{a}$ Top five most common patterns for interviews data only

${ }^{\mathrm{b}}$ Top five most common patterns for reflection data only

(--) indicate no mentions of this pattern

Fourteen total patterns emerged from analysis of the interview data, whereas nineteen emerged from the reflection data. In both data sets, collaborating, either as a singular interaction or paired with another interaction, occurred the most frequently among the patterns ( 9 of 14 times in the interview data and 12 of 19 in the reflection data) followed closely by integrating ( 9 of 14 times and 10 of 19 times) and mutual learning (9 of 14 times and 10 of 19 times). Emerging knowledge, either as a singular interaction or paired with another interaction occurred 5 of 14 times and 8 of 19 times, whereas defining the problem occurred least frequently across both data sets (3 of 14 times and 5 of 19 times). The pattern for the cumulative set of interactions required for the transdisciplinary knowledge production model, collaborating, defining the problem, integrating, mutual learning, and emerging knowledge (CDIME) only occurred in the interview data set (4 instances in the pre-course and 4 instances in the post-course data). The data provides evidence 
that there are significant differences between mentions of collaborating in the first and second sets of reflection data, and in mentions of integrating in the pre/post-course interview data. Additionally, a slight increase in understanding of interactions involved in transdisciplinary knowledge production occurs in the assessment survey results in Likert scale questions \#8, 9, and 10 (Table 9).

TABLE 9

STUDENT PRE/POST ASSESSMENT SURVEY RESULTS FOR QUESTIONS 8, 9, AND 10 REGARDING UNDERSTANDING OF INTERACTIONS INVOLVED IN TRANSDISCIPLINARY KNOWLEDGE PRODUCTION IN COMMUNITY-BASED DESIGN PROJECTS.

\section{Assessment Survey $(\mathbf{Q 8 ,} 9$ \& 10)}

For questions 8-11, indicate your agreement with each statement below. $(1=$ strongly disagree, $5=$ strongly agree $)$

\begin{tabular}{lll}
\hline & \multicolumn{2}{l}{ Mean Rank } \\
& \multicolumn{2}{l}{ EEE 495, N $\mathbf{1 5}$} \\
\cline { 2 - 3 } Pre & Post \\
\hline Creating transdisciplinary knowledge involves working together & 4.9 & 4.9 \\
Creating transdisciplinary knowledge involves combining knowledge & 4.7 & 4.9 \\
Creating transdisciplinary knowledge involves learning from others & 3.8 & 3.8 \\
\hline
\end{tabular}

The evidence presented across instruments for the construct interactions provides support for an increased awareness and understanding of the need to collaborate with stakeholders and integrate multiple knowledge sources and information in community-based design projects. The presence of mutual learning in multiple instances across the top five occurring patterns suggests an increased awareness and understanding of the value in learning from others, specifically stakeholders involved in the project. These results suggest that a transdisciplinary knowledge production model may enhance students' abilities to not only integrate non-technical dimensions, but also engage with stakeholders in community-based design projects, thus increasing sustainability problem-solving competencies.

\section{Converging Results Across Constructs}

Results across all three constructs, considerations, actors, and interactions, clearly demonstrate an increased awareness of, understanding of, and ability to apply non-technical dimensions to community-based design projects. In assessment survey Likert scale questions \#5, 6, and 7, students also reported that the educational intervention significantly increased their understanding of transdisciplinary knowledge production (Figure 8). 


\section{Understanding of Transdisciplinary Knowledge Production}

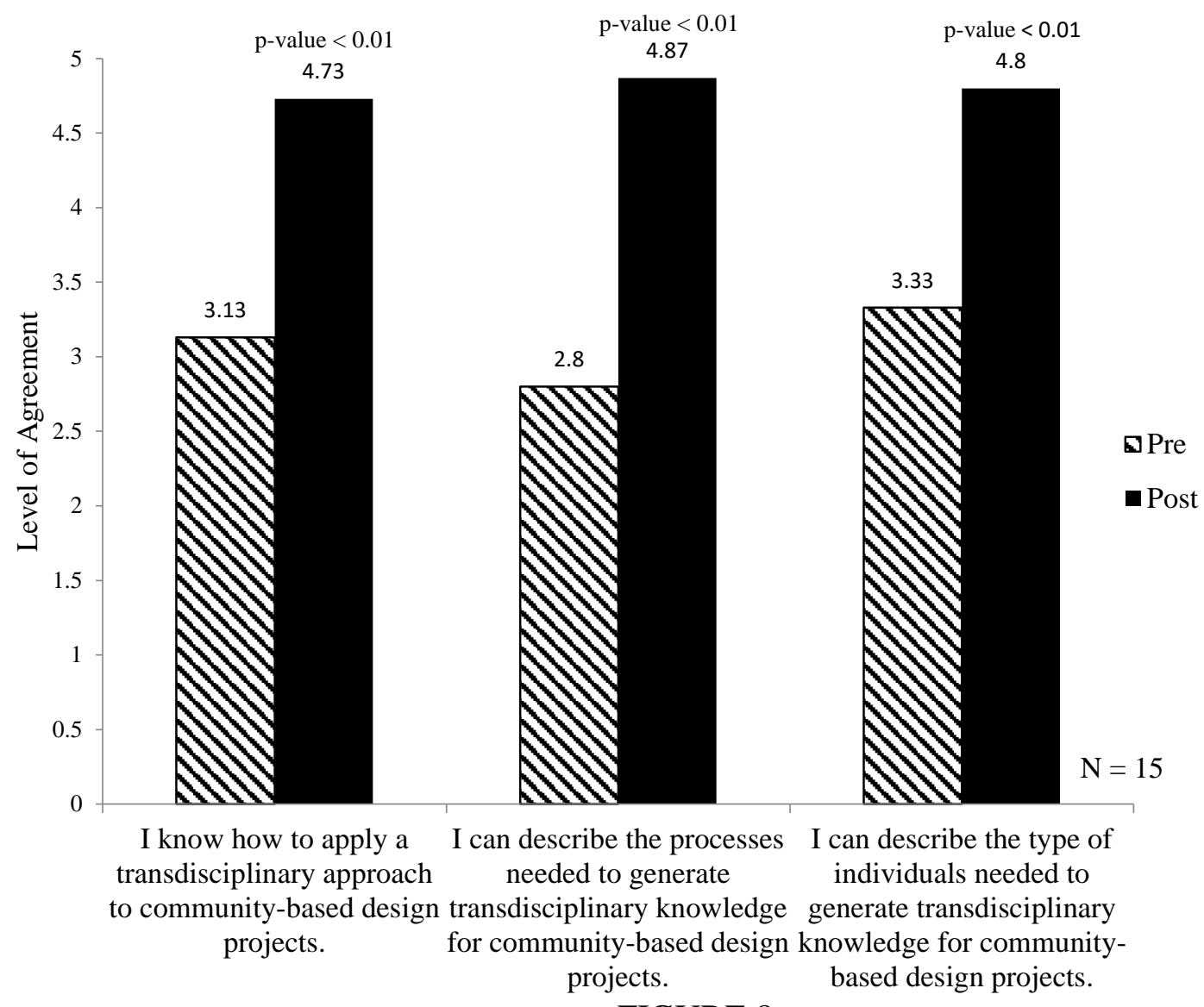

FIGURE 8

STUDENT PRE/POST-COURSE ASSESSMENT SURVEY RESULTS FOR QUESTIONS 5, 6, AND 7 REGARDING UNDERSTANDING OF TRANSDISCIPLINARY KNOWLEDGE PRODUCTION IN COMMUNITY-BASED DESIGN PROJECTS.

Holistically, these results also suggest the potential for a transdisciplinary knowledge production model to provide a platform for increasing sustainability problem-solving competencies in engineering, i.e., an understanding of the broader impact of design solutions and non-technical dimensions in design. While the previously mentioned results reveal strong support for the effectiveness of the intervention, the following two student excerpts from the second reflection data seek to qualitatively illustrate the connectivity between the transdisciplinary knowledge production-focused intervention and an increase in students' engineering competencies in sustainability problem solving. 
International Journal for Service Learning in Engineering, Humanitarian Engineering and Social Entrepreneurship

Vol. 13, No. 1, pp. 1-52, Spring 2018

ISSN 1555-9033

Excerpt One

"Teaching the principles of transdisciplinary knowledge to a student design team will both broaden each team member's perspective and improve the effectiveness of the team's project. Today's university student is given an in-depth education on their particular subject or field of study, and therefore regularly have biases regarding how to view and solve a problem; transdisciplinary knowledge opens new perspectives to these students and allows them to view both problems and solutions in a new light. Additionally, community-based projects are more effective when using a transdisciplinary approach. Since multiple players are collaborating, the final solution will serve everyone's needs as fully as possible. When the design team leaves the project at the end of the semester, they will see their work reflected in the project-but they will have also given the other players a stake in the project, and therefore the project is more likely to be maintained in the long term."

Excerpt Two

"This class is unique because it gives us, the students, an opportunity to interact and learn from people outside our university. This includes stakeholders, community members, and our project partner. For our project we have been in contact with many people outside of River University in order to ensure our success and create a design that is needed and welcomed by the community. So far we have met with and gained insight from the students at Johnson Middle School, faculty at Johnson Middle School and representatives from Urban Landscapers and River Stewards. Information gained from these interactions allows us to create a design with a high impact. Getting their input is imperative to our success and gives us a holistic view of the project and how it affects people in the community. Overall, the idea of transdisciplinary knowledge applies the concept of synergy and that collaboration with others outside of our academic discipline and academics in general will give us a result greater and more effective than anything we could have produced alone."

In the first except, phrases like "broaden each team member's perspective" and "opens new perspectives to these students and allows them to view both problems and solutions in a new light" indicate an increased awareness and understanding of non-technical dimensions to be included in community-based design projects, as well as the importance to including multiple stakeholders. This is also reflected in the second excerpt in statements such as "learn from people outside of our university. This includes stakeholders, community members, and our project partner and getting their input is imperative to our success and gives us a holistic view of the project." Phrases like "multiple players are collaborating" and "when the design team leaves the project...their work reflected in the project-but they will have also given the other players a stake" in the first excerpt, and "opportunity to interact and learn from people outside our university and collaboration with others outside of our academic discipline and academics in general will give us a result greater" in the second excerpt highlight the need for transdisciplinary knowledge production approaches. For additional interview and reflection data and further insights on this study see Payne. ${ }^{123}$ 
International Journal for Service Learning in Engineering, Humanitarian Engineering and Social Entrepreneurship

Vol. 13, No. 1, pp. 1-52, Spring 2018

ISSN 1555-9033

\section{DisCUSSION}

Results of this transdisciplinary knowledge production model-focused intervention in a PBL, service-learning environment provided evidence of an increase in students' awareness of, understanding of, and ability to apply non-technical dimensions in a community-based design project. Specifically, students demonstrated increased awareness and understanding of: stakeholder considerations, the need to collaborate with stakeholders, the need to integrate knowledge from multiple sources, and the importance of learning from stakeholders. This study further advances our understanding of appropriate learning environments, teaching methods, and assessment tools for developing engineering competencies in sustainability problem solving. While results from this study were not generalizable due to the small sample size, they are potentially transferable to similar classroom learning environments. There are, however, some important points of discussion to be addressed if this study is to be replicated in another setting. The following sections provide recommendations for future work and usage of the learning environment strategies, transdisciplinary knowledge production model, and assessment tools.

\section{The Stakeholder Story and Transdisciplinary Interactions}

The interventions described in this paper offered support for the learning of non-technical dimensions, specifically the "stakeholder story," i.e., an increase in students' awareness and understanding of stakeholder considerations, the need to collaborate with stakeholders, the need to integrate multiple sources of knowledge, and the importance of learning from stakeholders in engineering design as called for by various scholars and accreditation entities. ${ }^{124} 125126127$ This evidence points to clear linkages between the use of a PBL, service-learning environment and an increase in stakeholder engagement in community-based design projects concurring with the work of Al-Khafaji and Morse ${ }^{128}$ and Clevenger and Ozbek, ${ }^{129}$ as well as the broader body of literature on service-learning. Given the weekly contact students had with their community partners in the first intervention, this was an expected outcome. Less pronounced changes were also evident in the EPICS skill session data, suggesting that prolonged, consistent contact with partners is a critical component to enhancing this type of learning.

To a lesser degree, students' understanding of the suite of processes involved in the transdisciplinary knowledge production model was gained from this intervention. Thus, additional learning activities are likely needed to increase students' understanding of all of the interactions involved in the process and how those interactions help facilitate the inclusion of non-technical dimensions. Students clearly understood the need to collaborate, specifically with stakeholders, but were unable to consistently articulate other interactions, specifically the combination of interactions needed to produce transdisciplinary knowledge (i.e., CDIME-collaborating, defining the problem, integrating, mutual learning, and emerging knowledge-occurring only in the interview dataset). Hence, developing and deploying more structured, formalized activities to support learning in this regards would be beneficial.

Enhancing the stakeholder story and an understanding of the processes needed for transdisciplinary knowledge production could be supported by increased opportunities for critical reflection to generate, document, and deepen learning in experiential learning settings. ${ }^{130131} 132133$ In the engineering classroom specifically, Chen et al. ${ }^{134}$ have shown that the use of social media applications, i.e., weblogs, wikis, portfolios can increase reflective learning and positively 
influence students' knowledge, awareness, and skills in engineering design. Additionally, Schön ${ }^{135}$ suggests that reflection in action is a defining characteristic of professional practice and is critical for future practitioners in a variety of fields. In the classroom, large-group reflective discussions can be held intermittently throughout the semester to apply Schön's concept of reflection in action.

In the more specific context of understanding the broader impact of design solutions, i.e., nontechnical dimensions of design, it would be useful to have students explicitly identify different types of considerations included or excluded in the design process in small reflection assignments. In the reflection assignments used in the course described in this study, students were asked to reflect upon the transdisciplinary knowledge production process, but without necessarily explicitly highlighting design considerations. In these new, proposed assignments, students would describe not only how these considerations were included or excluded in their design, but also how awareness of such considerations impacted their problem-solving processes. Larger in-class group reflection opportunities categorizing considerations occurring in the design process might also help students reflect upon both their own and the class' growth in understanding of non-technical dimensions in community-based design, and perhaps also encourage growth in awareness and understanding of other considerations outside of stakeholder considerations (i.e., non-technical constraints and broader considerations, see Figure 3). In regards to the transdisciplinary knowledge production processes, additional in-class group reflection would also be beneficial. If staggered throughout the semester, this would provide students with opportunities to share the processes in which they had been engaging project stakeholders in real time, as well as offer an opportunity to link these real world experiences back to the theoretical model in a formalized, reinforcing learning environment.

A final point to address in the transdisciplinary knowledge production model is the low instances of mention of the interaction labeled defining the problem. As Downey ${ }^{136}$ has argued, this may be due to the fact that engineers are good at defining and solving technical problems, but are not as proficient at defining and solving problems on the "periphery." As this project involved an ill-defined problem coupled intimately with stakeholder needs, students struggled with bounding the issue and recognizing their role in the problem definition space. It may therefore be useful to reframe introductory lessons and activities to use problem scoping exercises and focus upon problem definition versus a traditional orientation toward problem solving. ${ }^{137}$ Another approach would be to create opportunities for students to participate in facilitating the partnership prior to taking a related course, which inherently includes defining, situating, and clarifying the problem among partners in the broader context. In this sense, students would help identify issues and develop relationships among partners from the outset.

\section{Fostering Sustainability Problem-Solving Competencies}

The use of a transdisciplinary knowledge production model additionally enriched the PBL and service-learning intervention by fostering the development of engineering competencies in sustainability problem solving, specifically in the area of offering frameworks for meaningful collaboration and knowledge integration among academics, practitioners, and stakeholders. ${ }^{138} 139$ 140141 Throughout the semester, students participated in off-site design charrettes with their community partners and collaboratively developed and refined their designs through multiple iterative feedback sessions via face-to-face contact, phone calls, and/or emails. They also collaborated with academics in stormwater management, hydrology, and native ecosystems. To 
International Journal for Service Learning in Engineering, Humanitarian Engineering and Social Entrepreneurship

Vol. 13, No. 1, pp. 1-52, Spring 2018

ISSN 1555-9033

complement the academic perspective, practitioners were brought into the classroom to talk about city stormwater management and local conservation efforts surrounding the river. Lastly, students worked closely with a green landscaping company to integrate their real-world, professional expertise into the project. This multi-pronged approach provided a foundation for applying the transdisciplinary knowledge production model in context, as sending students off campus to meet with their partner and bringing outside individuals into the classroom inherently placed value upon their expertise, as well as exposed students directly to multiple knowledge channels relevant to the project. This would not have occurred had a traditional pedagogical approach and model for knowledge production (i.e., multidisciplinary or interdisciplinary, see Figure 1) been employed. Nonetheless, it should be noted that implementing a course and model such as this can be resourceintensive, require higher level of flexibility in curriculum and assessments, introduce scheduling challenges due to differing timelines between the university and community partner, and ultimately require a willingness to give project control to students engaging in the experience. ${ }^{142}$

\section{Assessment Tools}

A third area of discussion revolves around the assessment tools emerging from this work. All effective educational practice involves systematic assessment of learning, and in this specific case, two emergent assessment instruments from the data analysis proved to be highly effective at this task: the actors coding rubric and the interactions coding rubric. While these instruments are context-specific, both could be modified for use in other learning environments, and thus be useful for those embarking upon similar curricular interventions and investigations, specifically providing support for the much needed documentation and assessment of transdisciplinary-focused curricular interventions as called for by Remington-Doucette et al. ${ }^{143}$ The actors coding rubric for individuals included and/or excluded in the transdisciplinary knowledge production model identified the frequency and type of actors with a very high inter-rater reliability, i.e., $94 \%$ in both the interview and reflection data analysis (see Figure 6). By modifying the definitions and providing relevant examples for each category within the rubric, this tool could be used in other design-based courses in engineering and other fields, such as technology, construction, landscape architecture, natural resources management, and urban planning, to assess the transdisciplinary knowledge production-focused curricular intervention.

The same could be done for the interactions rubric that codes for processes and methods included and/or excluded in the transdisciplinary knowledge production model. This rubric identified the frequency and type of the required interactions for the model (i.e., collaborating, defining the problem, integrating, mutual learning, and emerging knowledge, see Figure 7), again, with very high levels of inter-rater reliability, i.e., $87 \%$ in both the interview and reflection data analysis. This instrument also facilitated the identification of patterns in associated interactions. Both tools provided effective assessment measures for corroborating learning and/or identifying gaps in the learning of actors and interactions involved in the transdisciplinary knowledge production model.

It should also be noted that while these two assessment tools proved to be useful in this study, value would be added to a future study if additional instruments measuring students' abilities to apply non-technical dimensions in design were included. For instance, observational data could be collected during group presentations and stakeholder feedback sessions identifying considerations, actors, and interactions, as well as noting the inclusion or exclusion of these components into the 
International Journal for Service Learning in Engineering, Humanitarian Engineering and Social Entrepreneurship

Vol. 13, No. 1, pp. 1-52, Spring 2018

ISSN 1555-9033

design solution. It would also be useful to examine class artifacts, such as project proposals and design drafts, for the presence of non-technical dimensions, as well as actors and interactions associated with the transdisciplinary knowledge production model. Additionally, if time allowed, a larger sample of student interviewees would add richness to the study results.

\section{Self-Selection Story}

Lastly, it should be noted that there is a strong self-selection story likely influencing the results of this study given that students participating in the EEE 495 course from the outset exhibited greater tendencies toward involving stakeholders in community-based design projects, as evident in their high pre-course assessment scores. For instance, in Likert scale questions \#8, 9, 13, 15, and 17 all means were above 4.5 in the pre-course assessment $(4.9,4.7,4.9,4.7$, and 4.6, respectively) (Tables 7 and 9). Yet despite these high initial competency scores, evidence from this study suggests notable increases in competencies among even these high-performing students.

Additionally, three students from majors outside of engineering (e.g., political science, natural resources and environmental science, and landscape architecture) elected to take the course. As a result, there was potential for their different disciplinary perspectives to influence the engineering students' understanding of necessary design consideration. The interview and reflection data, however, demonstrated a surprising lack of explicit references to other disciplines when students were asked to identify design considerations. In fact, evidence of such awareness only occurred once, namely in the second set of reflection responses. This is likely a result of the transdisciplinary knowledge production model influencing students to subconsciously group themselves with all academic actors rather than separate their disciplinary perspectives (see Figure 2). Furthermore, efforts to focus on integrating knowledge outside of academia and enhance collaboration opportunities with community partners, through the transdisciplinary knowledge production model and service-learning pedagogical strategy, may have predisposed students to focus more intently upon external actors and knowledge versus different sources of disciplinary expertise internal to the academic context. Such dynamics would be worth further exploration and investigation in future educational interventions and/or research efforts.

\section{CONCLUSION}

This research addressed the need for engineering students to be more effective at integrating the non-technical dimensions of sustainability into their design solutions. It specifically assessed how a transdisciplinary knowledge production model-focused case study in an environmental and ecological engineering PBL, service-learning, community-based design course affected students' awareness of, understanding of, and ability to apply non-technical dimensions into design solutions, as well as increase their engineering competencies in sustainability problem solving. Three assessment techniques were used in a pre/post assessment approach: interviews, surveys, and reflections. Data were analyzed based upon the following constructs: considerations in design, as well as actors and interactions in transdisciplinary knowledge production.

From this work, the following three critical outcomes emerged. First, the results demonstrated that this specific intervention in community-based design increased students' awareness and understanding of: stakeholder considerations; the need to collaborate with stakeholders and integrate multiple knowledges and types; and the importance of learning from stakeholders. 
Second, the results suggest that a transdisciplinary knowledge production model may enhance the ability of students to not only integrate non-technical dimensions, but also engage with stakeholders in community-based design projects. Lastly, for educational practitioners, this research provided a roadmap for integrating these concepts into course pedagogical strategies, curricula, and assessments, specifically aligned with increasing students' learning surrounding non-technical dimensions in community-based design, as well as increasing their sustainability competencies.

\section{ACKNOWLEDGEMENTS}

The research team would like to thank the study participants who generously shared their time and experiences for the purposes of this project, as well as Dr. Nicole Iannone for conducting the data collection interviews. Lastly, the authors are grateful to Dr. Daniel Shepardson for his valuable insights and constructive feedback. 
International Journal for Service Learning in Engineering, Humanitarian Engineering and Social Entrepreneurship

Vol. 13, No. 1, pp. 1-52, Spring 2018

ISSN 1555-9033

\section{APPENDICES}

\section{Appendix A: Pre- \& Post-interviews}

\section{Pre-Interview Guide}

Script

Thank you for agreeing to participate in this study. As you know, this study is designed to evaluate the effectiveness of a curricular intervention on increasing engineering students' awareness, understanding, and ability to apply transdisciplinary knowledge in community-based design projects. As a participant in this pre-interview, at the end of the semester you will also be asked to participate in a post-interview which will take about 30 minutes. As a reminder, all of your responses will remain confidential and will not be reviewed until after grades are submitted. Lastly, if you complete all of the study procedures, you will receive $1 \%$ extra credit toward your overall course grade. This interview will be audio recorded. During the interview you may choose to not answer a question. Additionally, if you do not know the answer, please say so and we will move to the next question. Any questions?

Interviewee identifier

1. Please provide the last 4 digits of your cell phone \#:

Individual skills

2. What are your strongest design skills? Can you give any examples of specific projects or assignments where you used these skills?

3. What are your weakest design skills? Can you give any examples of specific projects or assignments where you became aware of these weaknesses?

Design concerns

4. In this course you will be participating in a community-based design project. What types of knowledge or design concerns might you want to incorporate into your project?

a. Follow-up probes for students who do not mention these types of considerations: What people or groups would be most important to involve? What knowledge or information might be most important to consider? What criteria do you think are most important to consider? What process(es) would you use for design? (Etc.)

5. What types of knowledge and/or design concerns do you think are least important or even irrelevant when doing a community-based design project?

Transdisciplinary knowledge

6. This course is titled: Transdisciplinary knowledge through innovative campus-community partnerships. How would you define transdisciplinary knowledge?

7. What processes might be involved in producing transdisciplinary knowledge?

8. What individuals might be involved in producing transdisciplinary knowledge?

9. How might you apply transdisciplinary knowledge to a community-based design project?

10. As a future professional, what barriers might prevent you from producing transdisciplinary knowledge? 
11. As a future professional, what might be some benefits associated with using a transdisciplinary approach to community-based design projects?

\section{Post-Interview Guide}

\section{Script}

Thank you again for agreeing to participate in this study. As you know, this study is designed to evaluate the effectiveness of a curricular intervention on increasing engineering students' awareness, understanding, and ability to apply transdisciplinary knowledge in community-based design projects. As a reminder, all of your responses will remain confidential and will not be reviewed until after grades are submitted. This interview will be audio recorded. During the interview you may choose to not answer a question. Additionally, if you do not know the answer, please say so and we will move to the next question. Any questions?

Interviewee identifier

1. Please provide the last 4 digits of your cell phone \#:

Individual skills

2. What are your strongest design skills? Can you give any examples of where you used these skills in the class projects?

3. What are your weakest design skills? Were these skills improved during the class, if so, how?

4. What are your career goals? i.e., in what type of job/organization do you see yourself working in the next 3-5 years?

Design concerns

5. In this course you have participated in a community-based design project. What types of knowledge or design concerns did you incorporate into your project?

a. Follow-up probes for students who do not mention these types of considerations: What people or groups would be most important to involve? What knowledge or information might be most important to consider? What criteria do you think are most important to consider? What process(es) would you use for design? (Etc.)

6. What types of knowledge and/or design concerns do you think are least important or even irrelevant when doing a community-based design project?

Transdisciplinary knowledge

7. This course is titled: Transdisciplinary knowledge through innovative campus-community partnerships. How would you define transdisciplinary knowledge?

8. What processes might be involved in producing transdisciplinary knowledge?

9. What individuals might be involved in producing transdisciplinary knowledge?

10. Provide examples of how you applied a transdisciplinary approach to your design project?

11. How useful was the transdisciplinary approach in designing your project? Please explain.

12. In your project you used a transdisciplinary approach in a design project with a local school, how might you use this type of approach in the future?

a. Follow up probe: in your future profession? 
International Journal for Service Learning in Engineering, Humanitarian Engineering and Social Entrepreneurship Vol. 13, No. 1, pp. 1-52, Spring 2018

ISSN 1555-9033

13. What barriers might prevent you from using a transdisciplinary approach in the future? How might you overcome these barriers?

a. Follow up probes: in your future profession? How might you overcome these barriers?

14. What might be some benefits associated with using a transdisciplinary approach in the future?

a. Follow up probe: in your future profession?

15. Lastly, in your class project it was apparent that communication was a key part of the transdisciplinary approach. Where would you place "communication" on the transdisciplinary approach framework?

a. Note: mark student's suggestion on the framework

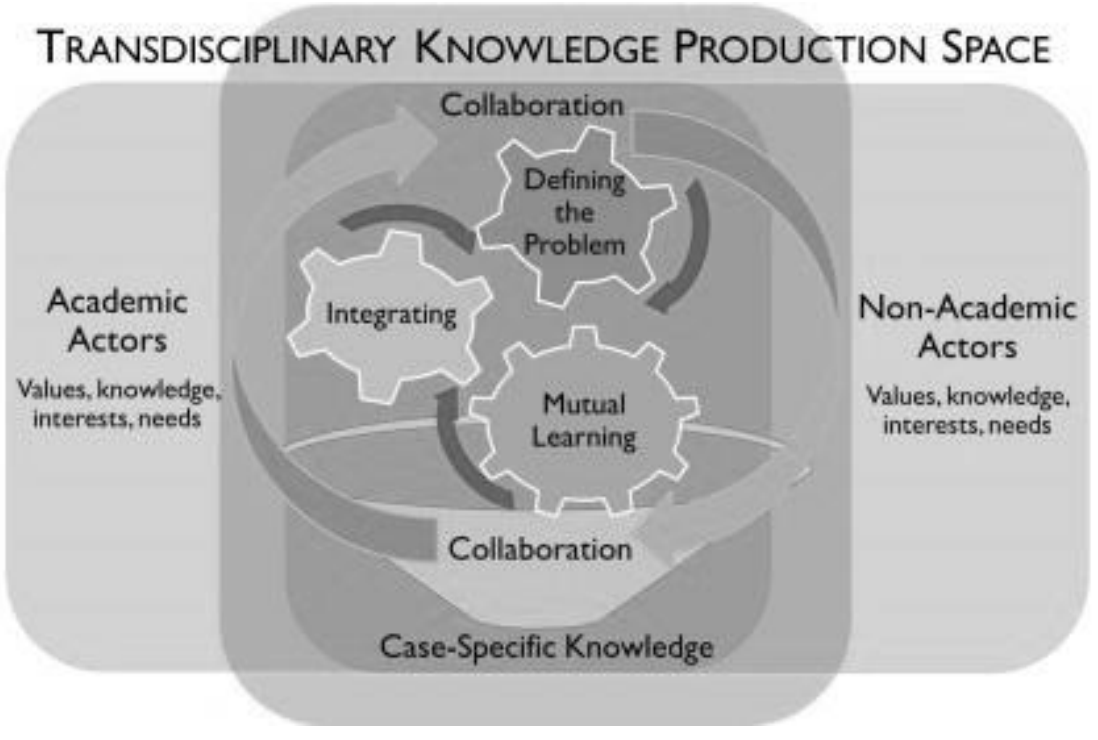




\section{Appendix B: Pre- \& Post-assessment survey}

\section{Pre-assessment survey}

This study is designed to evaluate the effectiveness of a curricular intervention on increasing engineering students' awareness, understanding, and ability to apply transdisciplinary knowledge in community-based design projects. For completing all study procedures, participating students will receive $1 \%$ extra credit toward their overall course grade. Students who do NOT complete all study procedures will NOT receive any compensation (extra credit). However, your participation in this study is strictly voluntary. You may choose not to participate or, if you agree to participate, you can withdraw your participation at any time without penalty or loss of benefits to which you are otherwise entitled. If you have questions, comments or concerns about this research project, please contact Dr. Brent Jesiek, 765-496-1531, bjesiek@ purdue.edu.

\section{Thank you in advance for your participation!}

1. For tracking purposes, please list the last 4 digits of your cell phone number. (Example: If the number is 949-357-4514, the response would be 4514.)

\section{Part 1 of 3: Scenario Questions}

Please answer questions 2 and 3 based on Scenario A.

Scenario A: In the small town of Waterville, storm water runoff into the local river is a critical problem leading to polluted waterways. Large-scale water management systems are currently in place to remediate the issue, but small-scale community-based projects are needed to further improve conditions and increase public awareness. Imagine that you and your team are assigned to design a small-scale water project in partnership with a local school and non-profit. The school experiences standing water after a rain event and all downspouts are directly connected to the storm water system which ultimately ends up in the local river untreated. The local non-profit specializing in community-based urban water projects has suggested installing a constructed wetland on the school grounds to alleviate these issues.

2. In your opinion, what are the five most important things that you need to consider in order to successfully accomplish this design task? Please list them below (a-e).

RANK (1-5)

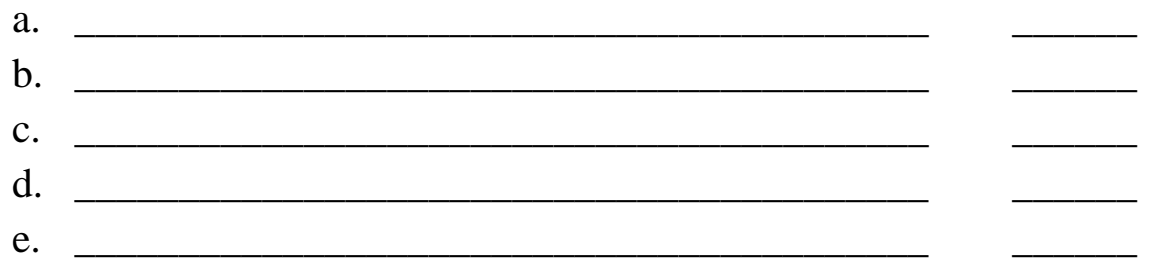

3. After you have written all five considerations, use the right-hand "RANK" column to RANK ORDER the relative importance of each consideration, from $1=$ most important down to 5=least important. 
Please answer question 4 based on Scenario B.

Scenario B: You have been asked to design a rain garden at a local science museum. You have a limited amount of time and resources to gather information that will be used throughout the duration of the design project.

4. From the following list, RANK ORDER the kinds of information you would MOST LIKELY NEED as you work on your design. ( $1=$ most important, $13=$ least important $)$

Availability of materials

Budget

Handicapped accessibility

Information about the site environment

Input from the museum curator

Labor and material cost

Legal liability

Neighborhood/user opinions

Safety

Supervision/maintenance concerns

Technical references/standards

Zoning/building codes and regulations

Other

\section{Part 2 of 3: Survey Questions}

For questions 5-7, please circle the number that best represents your perceptions. $(1$ = Strongly Disagree, 5 = Strongly Agree $)$

\begin{tabular}{|c|c|c|c|c|c|c|c|}
\hline 5. & $\begin{array}{l}\text { I know how to apply a transdisciplinary } \\
\text { approach to community-based design } \\
\text { projects. }\end{array}$ & $\begin{array}{l}\text { Strongly } \\
\text { Disagree }\end{array}$ & $\begin{array}{l}1 \\
5\end{array}$ & 2 & & & $\begin{array}{l}\text { Strongly } \\
\text { Agree }\end{array}$ \\
\hline 6. & $\begin{array}{l}\text { I can describe the processes needed to } \\
\text { generate transdisciplinary knowledge for } \\
\text { community-based design projects. }\end{array}$ & & & & & & \\
\hline 7. & $\begin{array}{l}\text { I can describe the type of individuals needed } \\
\text { to generate transdisciplinary knowledge for } \\
\text { community-based design projects. }\end{array}$ & & 5 & & & & \\
\hline
\end{tabular}


For questions 8-11, please mark an ' $x$ ' indicating your agreement with each statement below. Creating transdisciplinary knowledge involves...

8. $\quad$ Working together

9. Segmenting knowledge

10. Solving problems for others 11.

Non-Academics

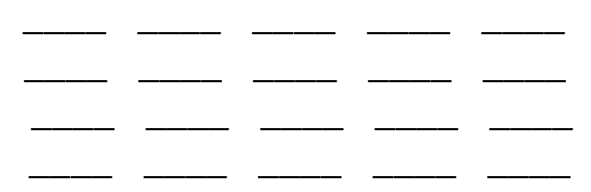

Working alone

Combining knowledge

Learning from others

Academics

12. When designing a local urban water project, RANK ORDER the relative importance of including each knowledge source. ( $1=$ most important, 7 = least important $)$

Stakeholders/users directly involved
General public
Academics
Non-academics
Field engineers/scientists
Policymakers/politicians
Contractors

For questions 13-19, please circle the number that best represents your perceptions. $(1$ = Strongly Disagree, 5 = Strongly Agree $)$

\begin{tabular}{|c|c|c|c|c|c|c|c|}
\hline 13. & $\begin{array}{l}\text { It is important to incorporate information } \\
\text { from multiple participants (scientists, } \\
\text { academics, stakeholders, general public) in } \\
\text { the community-based design process. }\end{array}$ & $\begin{array}{l}\text { Strongly } \\
\text { Disagree }\end{array}$ & $\begin{array}{l}1 \\
5\end{array}$ & 2 & 3 & 4 & $\begin{array}{l}\text { Strongly } \\
\text { Agree }\end{array}$ \\
\hline 14. & $\begin{array}{l}\text { Identifying environmental, social, political, } \\
\text { and economic issues surrounding local urban } \\
\text { water projects is not important in the design } \\
\text { process. }\end{array}$ & & $\begin{array}{l}1 \\
5\end{array}$ & 2 & 3 & 4 & \\
\hline 15. & $\begin{array}{l}\text { Considering local context (i.e., current uses } \\
\text { of the project site, opinions of those affected } \\
\text { by the projects, etc.) during the design } \\
\text { process is important. }\end{array}$ & & $\begin{array}{l}1 \\
5\end{array}$ & & & 4 & \\
\hline 16. & $\begin{array}{l}\text { Transdisciplinary knowledge is typically } \\
\text { generated by experts working alone. }\end{array}$ & $\begin{array}{l}\text { Strongly } \\
\text { Disagree }\end{array}$ & & & & & $\begin{array}{l}\text { Strongly } \\
\text { Agree }\end{array}$ \\
\hline 17. & $\begin{array}{l}\text { Academics and non-academics should } \\
\text { collaborate to create transdisciplinary } \\
\text { knowledge for community-based design } \\
\text { projects. }\end{array}$ & $\begin{array}{l}\text { Strongly } \\
\text { Disagree }\end{array}$ & $\begin{array}{l}1 \\
5\end{array}$ & & & 4 & $\begin{array}{l}\text { Strongly } \\
\text { Agree }\end{array}$ \\
\hline 18. & $\begin{array}{l}\text { Learning from others is not important when } \\
\text { creating transdisciplinary knowledge. }\end{array}$ & $\begin{array}{l}\text { Strongly } \\
\text { Disagree }\end{array}$ & $\begin{array}{l}1 \\
5\end{array}$ & & & & $\begin{array}{l}\text { Strongly } \\
\text { Agree }\end{array}$ \\
\hline
\end{tabular}




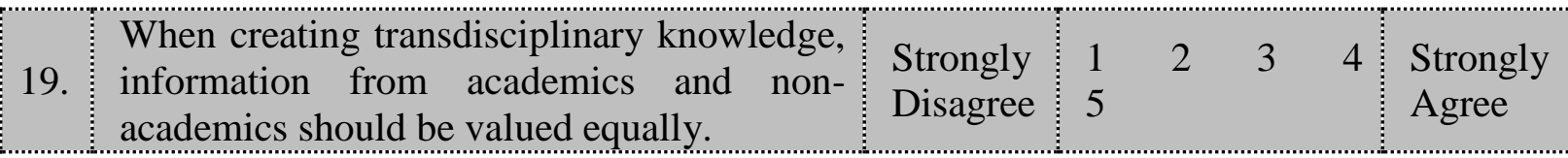

\section{Part 3 of 3: Demographic Questions}

20. What is your major?

21. What is your minor?

22. What is your current academic status?

First-year

Sophomore

Junior

Senior

Other:

23. What is your gender?
_ Male
Female
I prefer not to respond

24. What is your current age?

25. How do you describe your race and ethnicity?

African American or Black

American Indian/Alaska Native

East Asian

South Asian

Hispanic

Native Hawaiian or other Pacific Islander

White

Other/Mixed:

I prefer not to respond

26. Please indicate your primary country of citizenship:

27. I have participated in a design project with community partners and stakeholders, e.g., EPICS, Global Design Team, Engineers Without Borders, etc. Yes No Unsure

28. If your answer to the previous question was "Yes", approximately how many total semesters have you actively participated in such projects and where did they occur (city, state/region, and/or country)? 
International Journal for Service Learning in Engineering, Humanitarian Engineering and Social Entrepreneurship Vol. 13, No. 1, pp. 1-52, Spring 2018

ISSN 1555-9033

29. Would you be willing to participate in a short follow-up interview (30 minutes or less)? Yes No

\section{Thank you for your responses!}


International Journal for Service Learning in Engineering, Humanitarian Engineering and Social Entrepreneurship

Vol. 13, No. 1, pp. 1-52, Spring 2018

ISSN 1555-9033

\section{Post-assessment survey}

This study is designed to evaluate the effectiveness of a curricular intervention on increasing engineering students' awareness, understanding, and ability to apply transdisciplinary knowledge in community-based design projects. For completing all study procedures, participating students will receive $1 \%$ extra credit toward their overall course grade. Students who do NOT complete all study procedures will NOT receive any compensation (extra credit). However, your participation in this study is strictly voluntary. You may choose not to participate or, if you agree to participate, you can withdraw your participation at any time without penalty or loss of benefits to which you are otherwise entitled. If you have questions, comments or concerns about this research project, please contact Dr. Brent Jesiek, 765-496-1531, bjesiek@purdue.edu.

\section{Thank you in advance for your participation!}

1. For tracking purposes, please list the last 4 digits of your cell phone number. (Example: If the number is 949-357-4514, the response would be 4514.)

\section{Part 1 of 2: Scenario Questions}

\section{Please answer questions 2 and 3 based on Scenario $A$.}

Scenario A: In the small town of Waterville, storm water runoff into the local river is a critical problem leading to polluted waterways. Large-scale water management systems are currently in place to remediate the issue, but small-scale community-based projects are needed to further improve conditions and increase public awareness. Imagine that you and your team are assigned to design a small-scale water project in partnership with a local school and non-profit. The school experiences standing water after a rain event and all downspouts are directly connected to the storm water system which ultimately ends up in the local river untreated. The local non-profit specializing in community-based urban water projects has suggested installing a constructed wetland on the school grounds to alleviate these issues.

2. In your opinion, what are the five most important things that you need to consider in order to successfully accomplish this design task? Please list them below (a-e).

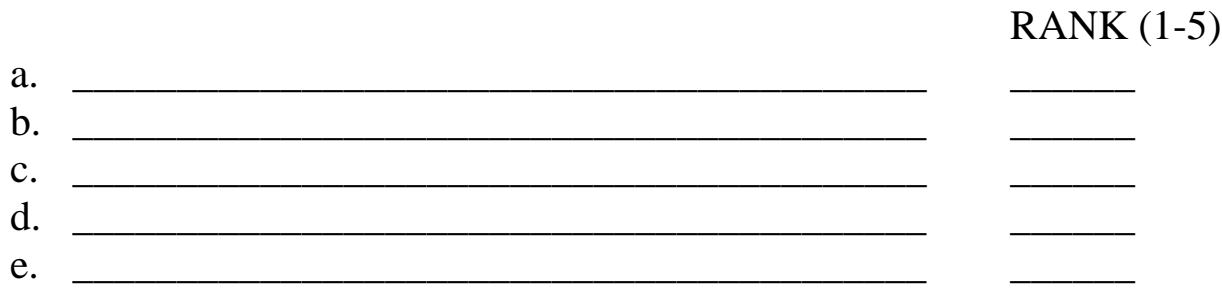

3. After you have written all five considerations, use the right-hand "RANK" column to RANK ORDER the relative importance of each consideration, from $1=$ most important down to $5=$ least important. 


\section{Please answer question 4 based on Scenario B.}

Scenario B: You have been asked to design a rain garden at a local science museum. You have a limited amount of time and resources to gather information that will be used throughout the duration of the design project.

4. From the following list, RANK ORDER the kinds of information you would MOST LIKELY NEED as you work on your design. ( $1=$ most important, $13=$ least important $)$

Availability of materials
Budget
Handicapped accessibility
Information about the site environment
Input from the museum curator
Labor and material cost
Legal liability
Neighborhood/user opinions
Safety
Supervision/maintenance concerns
Technical references/standards
Zoning/building codes and regulations
Other:

\section{Part 2 of 2: Survey Questions}

For questions 5-7, please circle the number that best represents your perceptions. $(1$ = Strongly Disagree, 5 = Strongly Agree $)$

\begin{tabular}{|l|l|l|l|l|l|l|l|} 
5. & $\begin{array}{l}\text { I know how to apply a transdisciplinary } \\
\text { approach to community-based design } \\
\text { projects. }\end{array}$ & $\begin{array}{l}\text { Strongly } \\
\text { Disagree }\end{array}$ & 5 & 2 & 3 & 4 & $\begin{array}{l}\text { Strongly } \\
\text { Agree }\end{array}$ \\
\hline 6. & $\begin{array}{l}\text { I can describe the processes needed to } \\
\text { generate transdisciplinary knowledge for } \\
\text { community-based design projects. }\end{array}$ & $\begin{array}{l}\text { Strongly } \\
\text { Disagree }\end{array}$ & $\begin{array}{l}1 \\
\text { com }\end{array}$ & 2 & 3 & 4 & $\begin{array}{l}\text { Strongly } \\
\text { Agree }\end{array}$ \\
\hline 7. & $\begin{array}{l}\text { I can describe the type of individuals needed } \\
\text { to generate transdisciplinary knowledge for } \\
\text { community-based design projects. }\end{array}$ & $\begin{array}{l}\text { Strongly } \\
\text { Disagree }\end{array}$ & 1 & 2 & 3 & 4 & $\begin{array}{l}\text { Strongly } \\
\text { Agree }\end{array}$ \\
\hline
\end{tabular}

For questions 8-11, please mark an ' $x$ ' indicating your agreement with each statement below. Creating transdisciplinary knowledge involves...

8. Working together

9. Segmenting knowledge

10. Solving problems for others
Working alone

Combining knowledge Learning from others 
11. Non-Academics Academics

12. When designing a local urban water project, RANK ORDER the relative importance of including each knowledge source. $(1=$ most important, $7=$ least important $)$

Stakeholders/users directly involved
General public
Academics
Non-academics
Field engineers/scientists
Policymakers/politicians
Contractors

For questions 13-19, please circle the number that best represents your perceptions. $(1$ = Strongly Disagree, 5 = Strongly Agree $)$

\begin{tabular}{|c|c|c|c|c|c|c|c|}
\hline 13. & $\begin{array}{l}\text { It is important to incorporate information } \\
\text { from multiple participants (scientists, } \\
\text { academics, stakeholders, general public) in } \\
\text { the community-based design process. }\end{array}$ & $\begin{array}{l}\text { Strongly } \\
\text { Disagree }\end{array}$ & $\begin{array}{l}1 \\
5\end{array}$ & 2 & 3 & 4 & $\begin{array}{l}\text { Strongly } \\
\text { Agree }\end{array}$ \\
\hline 14. & $\begin{array}{l}\text { Identifying environmental, social, political, } \\
\text { and economic issues surrounding local urban } \\
\text { water projects is not important in the design } \\
\text { process. }\end{array}$ & $\begin{array}{l}\text { Strongly } \\
\text { Disagree }\end{array}$ & 5 & 2 & 3 & 4 & $\begin{array}{l}\text { Strongly } \\
\text { Agree }\end{array}$ \\
\hline 15. & $\begin{array}{l}\text { Considering local context (i.e., current uses } \\
\text { of the project site, opinions of those affected } \\
\text { by the projects, etc.) during the design } \\
\text { process is important. }\end{array}$ & $\begin{array}{l}\text { Strongly } \\
\text { Disagree }\end{array}$ & 5 & 2 & 3 & 4 & $\begin{array}{l}\text { Strongly } \\
\text { Agree }\end{array}$ \\
\hline 16. & $\begin{array}{l}\text { Transdisciplinary knowledge is typically } \\
\text { generated by experts working alone. }\end{array}$ & $\begin{array}{l}\text { Strongly } \\
\text { Disagree }\end{array}$ & & & & 4 & $\begin{array}{l}\text { Strongly } \\
\text { Agree }\end{array}$ \\
\hline 17. & $\begin{array}{l}\text { Academics and non-academics should } \\
\text { collaborate to create transdisciplinary } \\
\text { knowledge for community-based design } \\
\text { projects. }\end{array}$ & $\begin{array}{l}\text { Strongly } \\
\text { Disagree }\end{array}$ & $\begin{array}{l}1 \\
5\end{array}$ & 2 & 3 & 4 & $\begin{array}{l}\text { Strongly } \\
\text { Agree }\end{array}$ \\
\hline 18. & $\begin{array}{l}\text { Learning from others is not important when } \\
\text { creating transdisciplinary knowledge. }\end{array}$ & $\begin{array}{l}\text { Strongly } \\
\text { Disagree }\end{array}$ & & & & 4 & $\begin{array}{l}\text { Strongly } \\
\text { Agree }\end{array}$ \\
\hline 19. & $\begin{array}{l}\text { When creating transdisciplinary knowledge, } \\
\text { information from academics and non- } \\
\text { academics should be valued equally. }\end{array}$ & $\begin{array}{l}\text { Strongly } \\
\text { Disagree }\end{array}$ & J & & 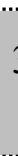 & 4 & $\begin{array}{l}\text { Strongly } \\
\text { Agree }\end{array}$ \\
\hline
\end{tabular}

20. In your project you used a transdisciplinary approach in a design project with a local school, how might you use this type of approach in the future? 
International Journal for Service Learning in Engineering, Humanitarian Engineering and Social Entrepreneurship Vol. 13, No. 1, pp. 1-52, Spring 2018

ISSN 1555-9033

\section{Thank you for your responses!}


International Journal for Service Learning in Engineering, Humanitarian Engineering and Social Entrepreneurship

Vol. 13, No. 1, pp. 1-52, Spring 2018

ISSN 1555-9033

\section{Appendix C: Pre- and post-reflections}

\section{Pre-Reflection}

Introduction - Critical reflection is the part of experiential learning that generates, deepens, and documents learning. When used in this capacity, it needs to be understood not as touchy-feely, non-grade-able, private, stream-of-consciousness, but rather as a reasoning process that is analytical, integrative, assessable, subject to public critique, and structured/guided. While reflection is not about generating one right answer, not all reasoning is equally valid. Reflection can be used to support learners in making reasoned judgments that are well-supported with evidence and that result from consideration of multiple perspective-not merely expressing opinions.

Framework - Reflect upon activities from previous classes and in one page, summarize what you have learned about the transdisciplinary knowledge, include a definition, interactions, and actors that should be involved - use your own words. Explain the benefits to this type of knowledge production. Include two ways in which you will approach the class design projects in order to produce transdisciplinary knowledge.

\begin{tabular}{|c|c|c|c|}
\hline Criteria & Unacceptable & Marginal & Superior \\
\hline Definition & $\begin{array}{l}0 \text { pts - A definition is not } \\
\text { provided. Response does not } \\
\text { demonstrate critical thought. }\end{array}$ & $\begin{array}{l}3 \text { pts - A marginally clear, } \\
\text { concise, and accurate definition is } \\
\text { provided. } \\
\begin{array}{l}\text { demonstrates } \\
\text { thought. }\end{array}\end{array}$ & $\begin{array}{l}5 \text { pts - A clear, concise, and } \\
\text { accurate definition is provided. } \\
\text { Response demonstrates critical } \\
\text { thought. }\end{array}$ \\
\hline Interactions & $\begin{array}{l}0 \text { pts - Interactions involved } \\
\text { in creating transdisciplinary } \\
\text { knowledge are not identified. } \\
\text { Response does not } \\
\text { demonstrate critical thought. }\end{array}$ & $\begin{array}{l}5 \text { pts - Interactions involved in } \\
\text { creating } \\
\text { knowledge are mansdisciplinary } \\
\text { identified. } \\
\begin{array}{l}\text { demonstrates } \\
\text { thought. }\end{array}\end{array}$ & $\begin{array}{l}10 \text { pts - Interactions involved in } \\
\text { creating transdisciplinary } \\
\text { knowledge are fully identified. } \\
\text { Response demonstrates critical } \\
\text { thought. }\end{array}$ \\
\hline Actors & $\begin{array}{l}0 \text { pts - Actors involved in } \\
\text { creating transdisciplinary } \\
\text { knowledge are not identified. } \\
\text { Response does not } \\
\text { demonstrate critical thought. }\end{array}$ & $\begin{array}{l}5 \text { pts - Actors involved in creating } \\
\text { transdisciplinary knowledge are } \\
\text { marginally identified. Response } \\
\text { demonstrates some critical } \\
\text { thought. }\end{array}$ & $\begin{array}{l}10 \text { pts - Actors involved in } \\
\text { creating transdisciplinary } \\
\text { knowledge are fully identified. } \\
\text { Response demonstrates critical } \\
\text { thought. }\end{array}$ \\
\hline Benefits & $\begin{array}{l}0 \text { pts - Examples are not } \\
\text { provided. Response does not } \\
\text { demonstrate critical thought. }\end{array}$ & $\begin{array}{l}5 \text { pts - Marginal examples are } \\
\text { provided regarding the benefits to } \\
\text { this type of production. Response } \\
\text { demonstrates some critical } \\
\text { thought. }\end{array}$ & $\begin{array}{l}10 \text { pts - Specific examples are } \\
\text { provided regarding the benefits } \\
\text { to this type of production. } \\
\text { Response demonstrates critical } \\
\text { thought. }\end{array}$ \\
\hline Application & $\begin{array}{l}0 \text { pts - Examples are not } \\
\text { provided. Response does not } \\
\text { demonstrate synthesis and } \\
\text { critical thought. }\end{array}$ & $\begin{array}{l}5 \text { pts - Marginal examples are } \\
\text { provided regarding the } \\
\text { application of a transdisciplinary } \\
\text { approach in the class design } \\
\text { project. Response demonstrates } \\
\text { some synthesis and critical } \\
\text { thought. }\end{array}$ & $\begin{array}{l}10 \text { pts - Two specific examples } \\
\text { are provided regarding the } \\
\text { application of a } \\
\text { transdisciplinary approach in } \\
\text { the class design project. } \\
\text { Response demonstrates } \\
\text { synthesis and critical thought. }\end{array}$ \\
\hline $\begin{array}{l}\text { Presentation } \\
\text { \& Polish }\end{array}$ & $\begin{array}{l}0 \text { pts - Response does not } \\
\text { demonstrate professionalism } \\
\text { and/or synthesis of } \\
\text { knowledge gained. }\end{array}$ & $\begin{array}{l}3 \text { pts - Response demonstrates } \\
\text { marginal professionalism and } \\
\text { synthesis of knowledge gained. }\end{array}$ & $\begin{array}{l}5 \text { pts - Response demonstrates } \\
\text { professionalism. It is concise, } \\
\text { clear and demonstrates a } \\
\text { synthesis of knowledge gained. }\end{array}$ \\
\hline
\end{tabular}


International Journal for Service Learning in Engineering, Humanitarian Engineering and Social Entrepreneurship

Vol. 13, No. 1, pp. 1-52, Spring 2018

ISSN 1555-9033

\section{Post-Reflection}

Introduction - Critical reflection is the part of experiential learning that generates, deepens, and documents learning. When used in this capacity, it needs to be understood not as touchy-feely, non-grade-able, private, stream-of-consciousness, but rather as a reasoning process that is analytical, integrative, assessable, subject to public critique, and structured/guided. While reflection is not about generating one right answer, not all reasoning is equally valid. Reflection can be used to support learners in making reasoned judgments that are well-supported with evidence and that result from consideration of multiple perspective-not merely expressing opinions.

Framework - In 1-2 pages, answer the following prompts related to applying a transdisciplinary approach to solving water sustainability issues in local design projects.

- What is transdisciplinary knowledge, and why would this concept be taught to students working with communities?

- Using specific examples, explain how its components will be applied in your context?

- What barriers have you experienced in trying to use transdisciplinary approaches in your project setting?

- What strategies do you have for overcoming these barriers and continuing to use a transdisciplinary approach to solving water sustainability issues in local design projects?

Rubric

\begin{tabular}{|c|c|c|c|}
\hline Criteria & Unacceptable & Marginal & Superior \\
\hline Definition & $\begin{array}{l}0 \text { pts - A definition is not } \\
\text { provided. Response does } \\
\text { not demonstrate critical } \\
\text { thought. }\end{array}$ & $\begin{array}{l}3 \text { pts - A marginally clear, concise, } \\
\text { and accurate definition is } \\
\text { provided. Response demonstrates } \\
\text { some critical thought. }\end{array}$ & $\begin{array}{l}5 \text { pts - A clear, concise, and } \\
\text { accurate definition is provided. } \\
\text { Response demonstrates critical } \\
\text { thought. }\end{array}$ \\
\hline Justification & $\begin{array}{l}0 \text { pts }- \text { A justifiable } \\
\text { argument is not provided. } \\
\text { Response does not } \\
\text { demonstrate } \\
\text { thought. }\end{array}$ & $\begin{array}{l}5 \text { pts - A marginally justifiable } \\
\text { argument is provided for teaching } \\
\text { this concept to students. Response } \\
\text { demonstrates some critical } \\
\text { thought. }\end{array}$ & $\begin{array}{l}10 \text { pts - A synthesized, justifiable } \\
\text { argument is provided for teaching } \\
\text { this concept to students. } \\
\text { Response demonstrates critical } \\
\text { thought. }\end{array}$ \\
\hline Application & $\begin{array}{l}0 \text { pts - Examples are not } \\
\text { provided. Response does } \\
\text { not demonstrate critical } \\
\text { thought. }\end{array}$ & $\begin{array}{l}5 \text { pts - Marginal examples are } \\
\text { provided regarding application in } \\
\text { context. Response demonstrates } \\
\text { some critical thought. }\end{array}$ & $\begin{array}{l}10 \text { pts - Specific examples are } \\
\text { provided regarding application in } \\
\text { context. Response demonstrates } \\
\text { critical thought. }\end{array}$ \\
\hline Barriers & $\begin{array}{l}0 \text { pts - Examples are not } \\
\text { provided. Response does } \\
\text { not demonstrate synthesis } \\
\text { and critical thought. }\end{array}$ & $\begin{array}{l}5 \text { pts - Marginal examples are } \\
\text { provided regarding barriers in } \\
\text { using a transdisciplinary approach } \\
\text { in the class design project. } \\
\text { Response demonstrates some } \\
\text { synthesis and critical thought. }\end{array}$ & $\begin{array}{l}10 \text { pts - Specific examples are } \\
\text { provided regarding barriers in } \\
\text { using a transdisciplinary } \\
\text { approach in the class design } \\
\text { project. Response demonstrates } \\
\text { synthesis and critical thought. }\end{array}$ \\
\hline Strategies & $\begin{array}{l}0 \text { pts }- \text { A complete list is } \\
\text { not provided. Response } \\
\text { does not demonstrate } \\
\text { synthesis and critical } \\
\text { thought. }\end{array}$ & $\begin{array}{l}5 \text { pts - A marginally complete list } \\
\text { of steps necessary to overcoming } \\
\text { barriers is provided. Marginal } \\
\text { examples are provided. Response } \\
\text { demonstrates some synthesis and } \\
\text { critical thought on personal } \\
\text { experience thus far. }\end{array}$ & $\begin{array}{l}10 \text { pts - A complete list of steps } \\
\text { necessary to overcoming barriers } \\
\text { is provided. Specific examples } \\
\text { are provided. Response } \\
\text { demonstrates synthesis and } \\
\text { critical thought on personal } \\
\text { experience thus far. }\end{array}$ \\
\hline
\end{tabular}


International Journal for Service Learning in Engineering, Humanitarian Engineering and Social Entrepreneurship

Vol. 13, No. 1, pp. 1-52, Spring 2018

ISSN 1555-9033

\begin{tabular}{|l|l|l|l|}
\hline $\begin{array}{l}\text { Presentation } \\
\text { \& Polish }\end{array}$ & $\begin{array}{l}0 \text { pts - Response does not } \\
\text { demonstrate } \\
\text { professionalism and/or } \\
\text { synthesis of knowledge } \\
\text { gained. }\end{array}$ & $\begin{array}{l}3 \text { pts - Response demonstrates } \\
\text { marginal professionalism and } \\
\text { synthesis of knowledge gained. }\end{array}$ & $\begin{array}{l}5 \text { pts - Response demonstrates } \\
\text { professionalism. It is concise, } \\
\text { clear and demonstrates a } \\
\text { synthesis of knowledge gained. }\end{array}$ \\
\hline
\end{tabular}

\section{REFERENCES}

${ }^{1}$ Brown, Valerie A., John Alfred Harris, and Jacqueline Y. Russell, eds. Tackling wicked problems through the transdisciplinary imagination. Earthscan, 2010.

2 Polk, Merritt. "Achieving the promise of transdisciplinarity: a critical exploration of the relationship between transdisciplinary research and societal problem solving." Sustainability science 9, no. 4 (2014): 439-451.

${ }^{3}$ Kates, Robert W., William C. Clark, Robert Corell, J. Michael Hall, Carlo C. Jaeger, Ian Lowe, James J. McCarthy. "Sustainability science." Science 292, no. 5517 (2001): 641-642.

${ }^{4}$ Komiyama, Hiroshi and Kazuhiko Takeuchi. "Sustainability science: building a new discipline." Sustainability Science 1, no. 1 (2006): 1-6.

${ }^{5}$ Clark, William C. "Sustainability science: a room of its own." Proceedings of the National Academy of Sciences 104, no. 6 (2007): 1737.

${ }^{6}$ Wiek, Arnim, Lauren Withycombe, and Charles L. Redman. "Key competencies in sustainability: a reference framework for academic program development." Sustainability science 6, no. 2 (2011): 203-218.

${ }^{7}$ National Academy of Engineering, U. S. The engineer of 2020: visions of engineering in the new century. Washington, DC: National Academies Press, 2004.

${ }^{8}$ Richter, David M. and Marie C. Paretti. "Identifying barriers to and outcomes of interdisciplinarity in the engineering classroom." European Journal of Engineering Education 34, no. 1 (2009): 29-45

${ }^{9}$ Brundiers, Katja, Arnim Wiek, and Charles L. Redman. "Real-world learning opportunities in sustainability: from classroom into the real world." International Journal of Sustainability in Higher Education 11, no. 4 (2010): 308-324.

${ }^{10}$ Frisk, Erin and Kelli L. Larson. "Educating for sustainability: Competencies \& practices for transformative action." Journal of Sustainability Education 2, no. 1 (2011): 1-20.

${ }^{11}$ Wiek, Arnim, Lauren Withycombe, and Charles L. Redman. "Key competencies in sustainability: a reference framework for academic program development." Sustainability science 6, no. 2 (2011): 203-218.

${ }^{12}$ ABET. "Criteria for Accrediting Engineering Programs, 2015 - 2016." 2014. http://www.abet.org/ accreditation/accreditation-criteria/.

${ }^{13}$ Siller, Thomas J. "Sustainability and critical thinking in civil engineering curriculum." Journal of Professional Issues in Engineering Education and Practice 127, no. 3 (2001): 104-108.

${ }^{14}$ Brewer, Graham, Thayaparan Gajendran, Chris Landorf, and T. Williams. "Educating for urban sustainability: a transdisciplinary approach." In Proceedings of the institution of civil engineers: engineering sustainability, vol. 161, no. 3, pp. 185-193. ICE Publishing, 2008. ${ }^{15}$ Sheppard, Sheri D., Kelly Macatangay, Anne Colby, and William M. Sullivan. Educating engineers: Designing for the future of the field. Vol. 2. Jossey-Bass, 2008. 
International Journal for Service Learning in Engineering, Humanitarian Engineering and Social Entrepreneurship Vol. 13, No. 1, pp. 1-52, Spring 2018

ISSN 1555-9033

${ }^{16}$ ABET. "Criteria for Accrediting Engineering Programs, 2015 - 2016." 2014. http://www.abet.org/ accreditation/accreditation-criteria/.

${ }^{17}$ ASCE. "Code of Ethics." 2006. http://www.asce.org/code-of-ethics/.

${ }^{18}$ Darwish, Muge Mukaddes and Mary Frances Agnello. "Sustainability/Green: Challenges and changes for educators and the engineering curriculum." In American Society for Engineering Education. American Society for Engineering Education, 2009.

${ }^{19}$ Downey, Gary Lee, Juan C. Lucena, Barbara M. Moskal, Rosamond Parkhurst, Thomas Bigley, Chris Hays, and Brent Jesiek. "The globally competent engineer: Working effectively with people who define problems differently." Journal of Engineering Education 95, no. 2 (2006): 107-122.

${ }^{20}$ Baker, Dan, John Merrill, and David Munoz. "Community development \& engineering: Perspectives on interdisciplinary projects in Honduras." In American Society for Engineering Education. American Society for Engineering Education, 2010.

${ }^{21}$ Downey, Gary Lee, Juan C. Lucena, Barbara M. Moskal, Rosamond Parkhurst, Thomas Bigley, Chris Hays, and Brent Jesiek. "The globally competent engineer: Working effectively with people who define problems differently." Journal of Engineering Education 95, no. 2 (2006): 107-122.

${ }^{22}$ Borrego, Maura and Lynita K. Newswander. "Characteristics of successful Cross-disciplinary engineering education collaborations." Journal of Engineering Education 97, no. 2 (2008): 123134.

${ }^{23}$ Borrego, Maura and Lynita K. Newswander. "Characteristics of successful Cross-disciplinary engineering education collaborations." Journal of Engineering Education 97, no. 2 (2008): 123134.

${ }^{24}$ Bordogna, Joseph, Eli Fromm, and Edward W. Ernst. "Engineering education: Innovation through integration." Journal of Engineering Education 82, no. 1 (1993): 3-8.

${ }^{25}$ Duderstadt, James J. "Engineering for a changing world a roadmap to the future of engineering practice, research, and education." 2008.

${ }^{26}$ Baker, Dan, John Merrill, and David Munoz. "Community development \& engineering: Perspectives on interdisciplinary projects in Honduras." In American Society for Engineering Education. American Society for Engineering Education, 2010.

${ }^{27}$ Downey, Gary Lee, Juan C. Lucena, Barbara M. Moskal, Rosamond Parkhurst, Thomas Bigley, Chris Hays, and Brent Jesiek. "The globally competent engineer: Working effectively with people who define problems differently." Journal of Engineering Education 95, no. 2 (2006): 107-122.

${ }^{28}$ Sheppard, Sheri D., Kelly Macatangay, Anne Colby, and William M. Sullivan. Educating engineers: Designing for the future of the field. Vol. 2. Jossey-Bass, 2008, 4.

${ }^{29}$ Downey, Gary Lee, Juan C. Lucena, Barbara M. Moskal, Rosamond Parkhurst, Thomas Bigley, Chris Hays, and Brent Jesiek. "The globally competent engineer: Working effectively with people who define problems differently." Journal of Engineering Education 95, no. 2 (2006): 107-122.

${ }^{30}$ Steiner, Mark, Junichi Kanai, Cheng Hsu, Eric H. Ledet, Jeff Morris, Mark Anderson, Scott Miller, Kurt Anderson, and Bharat Bagepalli. "Preparing Engineering Students for Professional Practice: Using Capstone to Drive Continuous improvement." International Journal of Engineering Education 31, no. 1 (2015): 154-164. 
International Journal for Service Learning in Engineering, Humanitarian Engineering and Social Entrepreneurship Vol. 13, No. 1, pp. 1-52, Spring 2018

ISSN 1555-9033

${ }^{31}$ Steiner, Mark, Junichi Kanai, Cheng Hsu, Eric H. Ledet, Jeff Morris, Mark Anderson, Scott Miller, Kurt Anderson, and Bharat Bagepalli. "Preparing Engineering Students for Professional Practice: Using Capstone to Drive Continuous improvement." International Journal of Engineering Education 31, no. 1 (2015): 154-164.

32 Martin, Rosanna, Bryan Maytham, Jennifer Case, and Duncan Fraser. "Engineering graduates' perceptions of how well they were prepared for work in industry." European journal of engineering education 30, no. 2 (2005): 167-180.

${ }^{33}$ Davidson, Cliff I., Chris T. Hendrickson, H. Scott Matthews, Michael W. Bridges, David T. Allen, Cynthia F. Murphy, Braden R. Allenby, John C. Crittenden, and Sharon Austin.

"Preparing future engineers for challenges of the 21st century: Sustainable engineering." Journal of cleaner production 18, no. 7 (2010): 698-701.

34 ABET. "Criteria for Accrediting Engineering Programs, 2015 - 2016." 2014.

http://www.abet.org/ accreditation/accreditation-criteria/.

${ }^{35}$ Nowotny, Helga, Peter Scott, Michael Gibbons, and Peter B. Scott. Re-thinking science:

Knowledge and the public in an age of uncertainty. Cambridge: Polity, 2001.

${ }^{36}$ Balsiger, Philip W. "Supradisciplinary research practices: history, objectives and rationale." Futures 36, no. 4 (2004): 407-421.

${ }^{37}$ Ravetz, Jerry. "The post-normal science of precaution." Futures 36, no. 3 (2004): 347-357.

${ }^{38}$ Wickson, Fern, Anna L. Carew, and Alice W. Russell. "Transdisciplinary research:

characteristics, quandaries and quality." Futures 38, no. 9 (2006): 1046-1059.

${ }^{39}$ Godemann, Jasmin. "Knowledge integration: A key challenge for transdisciplinary

cooperation." Environmental Education Research 14, no. 6 (2008): 625-641.

${ }^{40}$ Mendes, N.C. and M. Leach. "Understanding Timor-Leste." (2010).

${ }^{41}$ Borrego, Maura and Lynita K. Newswander. "Characteristics of successful Cross-disciplinary engineering education collaborations." Journal of Engineering Education 97, no. 2 (2008): 123-

134.

${ }^{42}$ Brown, Valerie A., John Alfred Harris, and Jacqueline Y. Russell, eds. Tackling wicked problems through the transdisciplinary imagination. Earthscan, 2010.

${ }^{43}$ Scholz, Roland W., and Claudia R. Binder. Environmental literacy in science and society: from knowledge to decisions. Cambridge University Press, 2011.

${ }^{44}$ Klein, Julie Thompson. "Prospects for transdisciplinarity." Futures 36, no. 4 (2004): 515-526.

45 Polk, Merritt. "Achieving the promise of transdisciplinarity: a critical exploration of the relationship between transdisciplinary research and societal problem solving." Sustainability science 9, no. 4 (2014): 439-451.

${ }^{46}$ Borrego, Maura and Lynita K. Newswander. "Characteristics of successful Cross-disciplinary engineering education collaborations." Journal of Engineering Education 97, no. 2 (2008): 123 134.

47 Schmuck, Peter. "Transdisciplinary evaluation of energy scenarios for a German village using multi-criteria decision analysis." Sustainability 4, no. 4 (2012): 604-629.

${ }^{48}$ Maheshwari, Basant, Maria Varua, John Ward, Roger Packham, Pennan Chinnasamy, Yogita Dashora, Seema Dave et al. "The role of transdisciplinary approach and community participation in village scale groundwater management: insights from Gujarat and Rajasthan, India." Water 6, no. 11 (2014): 3386-3408.

${ }^{49}$ Fam, Dena, and Abby Mellick Lopes. "Toilet practices and system change: lessons from a transdisciplinary research project." Journal of Design Research 13, no. 3 (2015): 307-322. 
${ }^{50}$ Stindt, Dennis, Ramin Sahamie, Christian Nuss, and Axel Tuma. "How transdisciplinarity can help to improve operations research on sustainable supply chains - a transdisciplinary modeling framework." Journal of Business Logistics 37, no. 2 (2016): 113-131.

${ }^{51}$ Remington-Doucette, Sonya M., Kim Y. Hiller Connell, Cosette M. Armstrong, and Sheryl L. Musgrove. "Assessing sustainability education in a transdisciplinary undergraduate course focused on real-world problem solving: a case for disciplinary grounding." International Journal of Sustainability in Higher Education 14, no. 4 (2013): 404-433.

${ }^{52}$ Ertas, Atila, Timothy Maxwell, Vicki P. Rainey, and Murat M. Tanik. "Transformation of higher education: the transdisciplinary approach in engineering." IEEE Transactions on Education 46, no. 2 (2003): 289-295.

${ }^{53}$ Jakobsen, Arne, and Louis L. Bucciarelli. "Transdisciplinary variation in engineering curricula. Problems and means for solutions." European journal of engineering education 32, no. 3 (2007): 295-301.

${ }^{54}$ Gumus, Bulent, Atila Ertas, Derrick Tate, and Ismail Cicek. "The transdisciplinary product development lifecycle model." Journal of Engineering Design 19, no. 3 (2008): 185-200.

${ }^{55}$ Exner, Konrad, Kai Lindow, Rainer Stark, Jussi Ängeslevä, Benjamin Bähr, and Emilia Nagy.

"A transdisciplinary perspective on prototyping." In Engineering, Technology and Innovation/International Technology Management Conference (ICE/ITMC), 2015 IEEE International Conference on, pp. 1-8. IEEE, 2015.

${ }^{56}$ Fielder, Darrell, Christiane C. Gattaz, U. John Tanik, Murat Tanik, and Fuad Sobrinho. "Transdisciplinary convergence-a vital consideration in engineering solutions." In SoutheastCon, 2016, pp. 1-8. IEEE, 2016.

${ }^{57}$ Kim, Kwanmyung, Namhun Kim, Seonhee Jung, Duck-Young Kim, Youngshin Kwak, and Gyouhyung Kyung. "A radically assembled design-engineering education program with a selection and combination of multiple disciplines." (2012).

${ }^{58}$ Hugill, Andrew, and Sophy Smith. "Digital creativity and transdisciplinarity at postgraduate level: the design and implementation of a transdisciplinary masters programme and its implications for creative practice." Digital Creativity 24, no. 3 (2013): 191-207.

${ }^{59}$ Kellam, Nadia, Joachim Walther, Tracie Costantino, and Bonnie Cramond. "Integrating the Engineering Curriculum through the Synthesis and Design Studio." Advances in Engineering Education 3, no. 3 (2013): n3.

${ }^{60}$ Walther, Joachim, Shari E. Miller, and Nicola W. Sochacka. "A model of empathy in engineering as a core skill, practice orientation, and professional way of being." Journal of Engineering Education 106, no. 1 (2017): 123-148.

${ }^{61}$ Borrego, Maura and Lynita K. Newswander. "Characteristics of successful Cross-disciplinary engineering education collaborations." Journal of Engineering Education 97, no. 2 (2008): 123134.

${ }^{62}$ Brown, Valerie A., John Alfred Harris, and Jacqueline Y. Russell, eds. Tackling wicked problems through the transdisciplinary imagination. Earthscan, 2010.

${ }^{63}$ Scholz, Roland W., and Claudia R. Binder. Environmental literacy in science and society: from knowledge to decisions. Cambridge University Press, 2011.

${ }^{64}$ Steinemann, Anne. "Implementing sustainable development through problem-based learning: Pedagogy and practice." Journal of Professional Issues in Engineering Education and Practice 129, no. 4 (2003): 216-224. 
International Journal for Service Learning in Engineering, Humanitarian Engineering and Social Entrepreneurship Vol. 13, No. 1, pp. 1-52, Spring 2018

ISSN 1555-9033

${ }^{65}$ Shuman, Larry J., Mary Besterfield-Sacre, and Jack McGourty. "The ABET "professional skills"- Can they be taught? Can they be assessed?." Journal of engineering education 94, no. 1 (2005): 41-55.

${ }^{66}$ Brundiers, Katja, Arnim Wiek, and Charles L. Redman. "Real-world learning opportunities in sustainability: from classroom into the real world." International Journal of Sustainability in Higher Education 11, no. 4 (2010): 308-324.

${ }^{67}$ Steiner, Mark, Junichi Kanai, Cheng Hsu, Eric H. Ledet, Jeff Morris, Mark Anderson, Scott Miller, Kurt Anderson, and Bharat Bagepalli. "Preparing Engineering Students for Professional Practice: Using Capstone to Drive Continuous improvement." International Journal of Engineering Education 31, no. 1 (2015): 154-164.

${ }^{68}$ Brundiers, Katja, Arnim Wiek, and Charles L. Redman. "Real-world learning opportunities in sustainability: from classroom into the real world." International Journal of Sustainability in Higher Education 11, no. 4 (2010): 308-324.

${ }^{69}$ Reckinger, Shanon, Joseph Bocchino, Andrew Jackowitz, and John Perry. "Rainwater Harvesting for Campus Student Center: A Sustainable, Community-Orientated Senior Design Project." International Journal for Service Learning in Engineering, Humanitarian Engineering and Social Entrepreneurship 9, no. 1 (2014): 117-137.

${ }^{70}$ Billiar, Kristen, Jeanne Hubelbank, Thomas Oliva, and Terri Camesano. "Teaching STEM by design." Advances in Engineering Education 4, no. 1 (2014): 1-21.

${ }^{71}$ Rhee, Jinny, Clifton M. Oyamot, Leslie Speer, David W. Parent, Anuradha Basu, and Larry N. Gerston. "A Case Study of a Co-Instructed Multidisciplinary Senior Capstone Project in Sustainability." Advances in Engineering Education 4, no. 2 (2014).

${ }^{72}$ Hanyak Jr, Michael E. "Conceptual Framework to Help Promote Retention and Transfer in the Introductory Chemical Engineering Course." Advances in Engineering Education 4, no. 3 (2015): n3.

${ }^{73}$ Secundo, Giustina, Giuseppina Passiante, A. L. D. O. Romano, and P. A. S. Q. U. A. L. E. Moliterni. "Developing the next generation of engineers for intelligent and sustainable manufacturing: A case study." International Journal of Engineering Education 29, no. 1 (2013): 248-262.

${ }^{74}$ Fang, Ning. "Improving engineering students' technical and professional skills through projectbased active and collaborative learning." International Journal of Engineering Education 28, no. 1 (2012): 26-36.

${ }^{75}$ Hatcher, Julie A., and Robert G. Bringle. "Reflection: Bridging the gap between service and learning." College teaching 45, no. 4 (1997): 153-158.

${ }^{76}$ Bringle, Robert G., and Julie A. Hatcher. "Institutionalization of service learning in higher education." The Journal of Higher Education 71, no. 3 (2000): 273-290.

${ }^{77}$ Coyle, Edward J., Leah H. Jamieson, and William C. Oakes. "EPICS: Engineering projects in community service." International Journal of Engineering Education 21, no. 1 (2005): 139-150.

${ }^{78} \mathrm{Al}-$ Khafaji, Karim, and Margaret Catherine Morse. "Learning sustainable design through service." International Journal for Service Learning in Engineering 1, no. 1 (2006): 1-10.

${ }^{79}$ Jawaharlal, Mariappan, Uei-Jiun Fan, and Saeed Monemi. "Implementing service-learning in engineering curriculum." In Proceedings of the ASEE Annual Conference and Exposition, no. 2614. 2006. 
International Journal for Service Learning in Engineering, Humanitarian Engineering and Social Entrepreneurship Vol. 13, No. 1, pp. 1-52, Spring 2018

ISSN 1555-9033

${ }^{80}$ National Academy of Engineering, U. S. "U.S. engineering schools to educate 20,000 students to meet grand challenges." 2015.

http://www.nae.edu/Projects/MediaRoom/20095/130169/134046.aspx

${ }^{81}$ Shuman, Larry J., Mary Besterfield-Sacre, and Jack McGourty. "The ABET "professional skills"-Can they be taught? Can they be assessed?." Journal of engineering education 94, no. 1 (2005): 41-55.

${ }^{82}$ Selingo, Jeffrey. "May I help you?" ASEE Prism 15, no. 9 (2006): 40.

${ }^{83}$ Dinehart, David W., and Shawn P. Gross. "A service learning structural engineering capstone course and the assessment of technical and non-technical objectives." Advances in Engineering Education 2, no. 1 (2010): n1.

${ }^{84}$ Bielefeldt, Angela R., Mandar M. Dewoolkar, Kevin M. Caves, Bruce W. Berdanier, and Kurtin G. Paterson. "Diverse models for incorporating service projects into engineering capstone design courses." International Journal of Engineering Education 27, no. 6 (2011): 1206.

${ }^{85}$ Budny, Dan, and Robert Thomas Gradoville. "International service learning design projects: Educating tomorrow's engineers, serving the global community, and helping to meet ABET criterion." International Journal for Service Learning in Engineering, Humanitarian Engineering and Social Entrepreneurship 6, no. 2 (2011): 98-117.

${ }^{86}$ Duffy, John, Linda Barrington, Cheryl West, Manuel Heredia, and Carol Barry. "Servicelearning integrated throughout a college of engineering (SLICE)." Advances in Engineering Education 2, no. 4 (2011): n4.

${ }^{87}$ ABET. "Criteria for Accrediting Engineering Programs, 2015 - 2016." 2014. http://www.abet.org/ accreditation/accreditation-criteria/.

${ }^{88}$ Hatcher, Julie A., and Robert G. Bringle. "Reflection: Bridging the gap between service and learning." College Teaching 45, no. 4 (1997): 153-158.

${ }^{89}$ Bringle, Robert G., and Julie A. Hatcher. "Institutionalization of service learning in higher education." The Journal of Higher Education 71, no. 3 (2000): 273-290.

${ }^{90}$ Franquesa, D., Cruz, J. L., Alvarez, C., Sanchez, F., Fernandez, A., \& Lopez, D. (2010). The social and environmental impact of engineering solutions: from the lab to the real world. International Journal of Engineering Education, 26(5), 1144-1155.

${ }^{91}$ Dukhan, Nihad, Mark R. Schumack, and John J. Daniels. "Implementation of service-learning in engineering and its impact on students' attitudes and identity." European Journal of Engineering Education 33, no. 1 (2008): 21-31.

${ }^{92}$ Fang, Ning. "Improving engineering students' technical and professional skills through projectbased active and collaborative learning." International Journal of Engineering Education 28, no. 1 (2012): 26-36.

${ }^{93}$ Coyle, Edward J., Leah H. Jamieson, and William C. Oakes. "EPICS: Engineering projects in community service." International Journal of Engineering Education 21, no. 1 (2005): 139-150. 94 Al-Khafaji, Karim, and Margaret Catherine Morse. "Learning sustainable design through service." International Journal for Service Learning in Engineering 1, no. 1 (2006): 1-10. 95 Al-Khafaji, Karim, and Margaret Catherine Morse. "Learning sustainable design through service." International Journal for Service Learning in Engineering 1, no. 1 (2006): 1-10. ${ }^{96}$ Clevenger, Caroline M., and Mehmet E. Ozbek. "Service-learning assessment: Sustainability competencies in construction education." Journal of Construction Engineering and Management 139, no. 12 (2013): A4013010. 
International Journal for Service Learning in Engineering, Humanitarian Engineering and Social Entrepreneurship Vol. 13, No. 1, pp. 1-52, Spring 2018

ISSN 1555-9033

${ }^{97}$ Hayden, Nancy J., Donna M. Rizzo, Mandar M. Dewoolkar, Maureen D. Neumann, Sandra Lathem, and A. D. E. L. Sadek. "Incorporating a systems approach into civil and environmental engineering curricula: Effect on course redesign, and student and faculty attitudes." Advances in Engineering Education 2, no. 4 (2011): n4.

98 Yin, Robert K. "Case study research: design and methods, Applied social research methods series." Thousand Oaks, CA: Sage Publications, Inc. Afacan, Y., \& Erbug, C.(2009). An interdisciplinary heuristic evaluation method for universal building design. Journal of Applied Ergonomics 40 (2003): 731-744.

${ }^{99}$ Payne, Lindsey. "Transitioning to Sustainability through Transdisciplinary Knowledge Production Models." PhD diss., Purdue University, 2015.

${ }^{100}$ Payne, Lindsey. "Transitioning to Sustainability through Transdisciplinary Knowledge Production Models." PhD diss., Purdue University, 2015.

101 Zoltowski, Carla B., and William C. Oakes. "Learning by Doing: Reflections of the EPICS Program." International Journal for Service Learning in Engineering 9 (2014).

102 Patton, M. Q. "Qualitative research and methods." Thousand Oaks. (2002).

103 Yin, Robert K. "Case study research: design and methods, Applied social research methods series." Thousand Oaks, CA: Sage Publications, Inc. Afacan, Y., \& Erbug, C.(2009). An interdisciplinary heuristic evaluation method for universal building design. Journal of Applied Ergonomics 40 (2003): 731-744.

${ }^{104}$ Borrego, Maura, Elliot P. Douglas, and Catherine T. Amelink. "Quantitative, qualitative, and mixed research methods in engineering education." Journal of Engineering education 98, no. 1 (2009): 53-66.

${ }^{105}$ Creswell, John W., and J. David Creswell. Research design: Qualitative, quantitative, and mixed methods approaches. Sage Publications, 2017.

106 Yin, Robert K. "Case study research: design and methods, Applied social research methods series." Thousand Oaks, CA: Sage Publications, Inc. Afacan, Y., \& Erbug, C.(2009). An interdisciplinary heuristic evaluation method for universal building design. Journal of Applied Ergonomics 40 (2003): 731-744.

${ }^{107}$ Boyatzis, Richard E. Transforming qualitative information: Thematic analysis and code development. Sage Publications, 1998.

${ }^{108}$ Boyatzis, Richard E. Transforming qualitative information: Thematic analysis and code development. Sage Publications, 1998.

${ }^{109}$ Yin, Robert K. "Case study research: design and methods, Applied social research methods series." Thousand Oaks, CA: Sage Publications, Inc. Afacan, Y., \& Erbug, C.(2009). An interdisciplinary heuristic evaluation method for universal building design. Journal of Applied Ergonomics 40 (2003): 731-744.

${ }^{110}$ Creswell and Creswell. Research design: Qualitative, quantitative, and mixed methods approaches. Sage Publications, 2017.

${ }^{111}$ Dinehart, David W., and Shawn P. Gross. "A service learning structural engineering capstone course and the assessment of technical and non-technical objectives." Advances in Engineering Education 2, no. 1 (2010): n1.

112 Chan, Cecilia Ka Yuk. "Assessment for community service types of experiential learning in the engineering discipline." European Journal of Engineering Education 37, no. 1 (2012): 29-38. 113 Bringle, Robert G., and Julie A. Hatcher. "Institutionalization of service learning in higher education." The Journal of Higher Education 71, no. 3 (2000): 273-290. 
International Journal for Service Learning in Engineering, Humanitarian Engineering and Social Entrepreneurship Vol. 13, No. 1, pp. 1-52, Spring 2018

ISSN 1555-9033

${ }^{114}$ Bringle, Robert G., Julie A. Hatcher, and Patti H. Clayton, eds. Research on service learning: conceptual frameworks and assessments. Stylus Publishing, LLC, 2013.

115 Jesiek, Brent and Sang Eun Woo. "Realistic assessment for realistic instruction: Situational assessment strategies for engineering education and practice." In Proceedings of the 2011 SEFI Annual Conference, Lisbon, Portugal. 2011.

${ }^{116}$ Jesiek, Brent, Yating Haller, and Julia Thompson. "Developing Globally Competent Engineering Researchers: Outcomes-Based Instructional and Assessment Strategies from the IREE 2010 China Research Abroad Program." Advances in Engineering Education 4, no. 1 (2014): n1.

${ }^{117}$ Patton, M. Q. "Qualitative research and methods." Thousand Oaks. (2002).

${ }^{118}$ Yin, Robert K. "Case study research: design and methods, Applied social research methods series." Thousand Oaks, CA: Sage Publications, Inc. Afacan, Y., \& Erbug, C.(2009). An interdisciplinary heuristic evaluation method for universal building design. Journal of Applied Ergonomics 40 (2003): 731-744.

${ }^{119}$ Mazzurco, Andrea, James L. Huff, and Brent Jesiek. "The energy conversion playground (ECP) design task: assessing how students think about technical and non-technical considerations in sustainable community development." International Journal for Service Learning in Engineering 9, no. 2 (2014): 64-84.

${ }^{120}$ Mazzurco, Andrea, James L. Huff, and Brent Jesiek. "The energy conversion playground (ECP) design task: assessing how students think about technical and non-technical considerations in sustainable community development." International Journal for Service Learning in Engineering 9, no. 2 (2014): 64-84.

${ }^{121}$ Ash, Sarah L., and Patti H. Clayton. "Generating, deepening, and documenting learning: The power of critical reflection in applied learning." (2009).

${ }^{122}$ Bringle, Robert G., Julie A. Hatcher, and Patti H. Clayton, eds. Research on service learning: conceptual frameworks and assessments. Stylus Publishing, LLC, 2013.

${ }^{123}$ Payne, Lindsey. "Transitioning to Sustainability through Transdisciplinary Knowledge Production Models." PhD diss., Purdue University, 2015.

${ }^{124}$ Martin, Rosanna, Bryan Maytham, Jennifer Case, and Duncan Fraser. "Engineering graduates' perceptions of how well they were prepared for work in industry." European journal of engineering education 30, no. 2 (2005): 167-180.

${ }^{125}$ Downey, Gary Lee, Juan C. Lucena, Barbara M. Moskal, Rosamond Parkhurst, Thomas Bigley, Chris Hays, and Brent Jesiek. "The globally competent engineer: Working effectively with people who define problems differently." Journal of Engineering Education 95, no. 2 (2006): 107-122.

${ }^{126}$ Davidson, Cliff I., Chris T. Hendrickson, H. Scott Matthews, Michael W. Bridges, David T. Allen, Cynthia F. Murphy, Braden R. Allenby, John C. Crittenden, and Sharon Austin. "Preparing future engineers for challenges of the 21st century: Sustainable engineering." Journal of cleaner production 18, no. 7 (2010): 698-701.

${ }^{127}$ ABET. "Criteria for Accrediting Engineering Programs, 2015 - 2016." 2014. http://www.abet.org/ accreditation/accreditation-criteria/.

${ }_{128}$ Al-Khafaji, Karim, and Margaret Catherine Morse. "Learning sustainable design through service." International Journal for Service Learning in Engineering 1, no. 1 (2006): 1-10. 
International Journal for Service Learning in Engineering, Humanitarian Engineering and Social Entrepreneurship Vol. 13, No. 1, pp. 1-52, Spring 2018

ISSN 1555-9033

${ }^{129}$ Clevenger, Caroline M., and Mehmet E. Ozbek. "Service-learning assessment: Sustainability competencies in construction education." Journal of Construction Engineering and Management 139, no. 12 (2013): A4013010.

${ }^{130}$ Bringle, Robert G., and Julie A. Hatcher. "Institutionalization of service learning in higher education." The Journal of Higher Education 71, no. 3 (2000): 273-290.

${ }^{131}$ Ash, Sarah L., and Patti H. Clayton. "Generating, deepening, and documenting learning: The power of critical reflection in applied learning." (2009).

${ }^{132}$ Chan, Cecilia Ka Yuk. "Assessment for community service types of experiential learning in the engineering discipline." European Journal of Engineering Education 37, no. 1 (2012): 29-38. ${ }^{133}$ Bringle, Robert G., Julie A. Hatcher, and Patti H. Clayton, eds. Research on service learning: conceptual frameworks and assessments. Stylus Publishing, LLC, 2013.

${ }^{134}$ Chen, Helen L., David Cannon, Jonathan Gabrio, Larry Leifer, George Toye, and Tori Bailey. "Using wikis and weblogs to support reflective learning in an introductory engineering design course." Human Behaviour in Design 5 (2005): 95-105.

${ }^{135}$ Schon, D. A. "1983 The reflective practitioner: How professionals think in action." New York: Basic Books. (1983).

${ }^{136}$ Downey, Gary. "Are engineers losing control of technology?: From 'problem solving'to 'problem definition and solution' in engineering education." Chemical Engineering Research and Design 83, no. 6 (2005): 583-595.

${ }^{137}$ Downey, Gary. "Are engineers losing control of technology?: From 'problem solving'to 'problem definition and solution' in engineering education." Chemical Engineering Research and Design 83, no. 6 (2005): 583-595.

${ }^{138}$ Borrego, Maura and Lynita K. Newswander. "Characteristics of successful Cross-disciplinary engineering education collaborations." Journal of Engineering Education 97, no. 2 (2008): 123134.

${ }^{139}$ Brown, Valerie A., John Alfred Harris, and Jacqueline Y. Russell, eds. Tackling wicked problems through the transdisciplinary imagination. Earthscan, 2010.

${ }^{140}$ Brundiers, Katja, Arnim Wiek, and Charles L. Redman. "Real-world learning opportunities in sustainability: from classroom into the real world." International Journal of Sustainability in Higher Education 11, no. 4 (2010): 308-324.

${ }^{141}$ Scholz, Roland W., and Claudia R. Binder. Environmental literacy in science and society: from knowledge to decisions. Cambridge University Press, 2011.

${ }_{142}$ Jacoby, Barbara. Service-learning essentials: questions, answers, and lessons learned. John Wiley \& Sons, 2014.

${ }^{143}$ Remington-Doucette, Sonya M., Kim Y. Hiller Connell, Cosette M. Armstrong, and Sheryl L. Musgrove. "Assessing sustainability education in a transdisciplinary undergraduate course focused on real-world problem solving: a case for disciplinary grounding." International Journal of Sustainability in Higher Education 14, no. 4 (2013): 404-433. 